\title{
Wrongs, Rights, and Remedies: A Yankee Romp in Recent European Tort Law Richard J. Peltz-Steele*
}

\begin{abstract}
This article explores developments in European tort law reported by country at the 2015 European Tort Law Institute. Reported developments were selected for recurring themes and compared with analogous problems in U.S. tort law. Though by no means a statistical survey, the reports are indicative of contemporary issues of interest to informed European lawyers and educators. The recurring themes were (a) damages valuation and compensation for life and death; (b) multiple liabilities; $(c)$ interplay of tort and insurance; $(d)$ official liability and civil rights; and (e) consumer class actions. Analyzing these threads, the article concludes (1) that U.S. and European courts reason similarly on common problems in tort logistics, but differ in justification for employing equity and policy norms; (2) that U.S. and European courts similarly tend to defer to tort legislation, though differ in willingness to imbue statutory construction with normative discretion; and (3) that at least the sampled European courts exhibited a greater willingness than is common among U.S. courts to champion individual causes against the state. These comparisons afford an opportunity to study legal systems of variable geographic and cultural origin, and of common law and civil code tradition, as they wrestle with the simple yet intractable problem of how society should respond to civil wrongs.
\end{abstract}

\section{I. INTRODUCTION}

Each spring, the European Tort Law Institute holds a conference in which representatives of European Union states are invited to present the most interesting developments in tort law from their respective jurisdictions in the preceding year. ${ }^{1}$ Of course these selective reports are not necessarily representative of statistically significant trends in the law. Nevertheless, a survey of what informed European observers find compelling is useful for comparative studies. Problems in civil liability transcend borders and cultures. Lawyers and educators in tort law stand to gain

\footnotetext{
* Professor, University of Massachusetts Law School. I am indebted to Emma Wood, M.L.S., and Megan Beyer, J.D. anticipated 2016, for dedicated work in tracking down primary sources for this study. A research grant from UMass Law School also made this study possible. I am most grateful to the organizers of and delegates to the European Tort Law Institute, infra note 1, for a supremely educational program.

${ }^{1}$ European Centre of Tort and Insurance Law Institute for European Tort Law, 14th Annual Conference on European Tort Law, Vienna, Austria [hereinafter Institute], (Apr. 9-11, 2015).
} 
from even a selective examination of how people from different legal traditions respond to the common policy problems of our time.

Accordingly, part II of this article reiterates selected developments reported by delegates to the 2015 conference, delving into the primary sources to capture a snapshot of contemporary issues in European tort law, ${ }^{2}$ and aligning those images alongside U.S. legal doctrine for comparison. The developments are selected and organized to identify recurring themes, namely: (a) damages valuation and compensation for life and death; (b) multiple liabilities; (c) the interplay of tort and insurance; (d) official liability and civil rights; and (e) consumer class actions. ${ }^{3}$ This reiteration at best might inform the debate over comparable questions in U.S. tort law and at least might serve to educate students of U.S. law in comparative studies.

Accordingly, parts III and IV of this article modestly offer analysis and three conclusions. The article concludes first that when controversy centers on the mundane logistics of tort law, such as damages valuation and liability apportionment, there is great commonality between the United States and Europe in courts' reasoning on similar problems. However, European courts are far more likely than U.S. courts to state the explicit influence of human rights norms in construing civil codes, while U.S. courts rely more vaguely on the role of equity and public policy in shaping the common law. The article concludes second that when political policymaking comes into play, it manifests the respective policy priorities of U.S. and European legislators. Courts in both systems tend to respect the legislative prerogative, though U.S. courts are somewhat less inclined than European courts to let their own policy priorities supervene upon libertarian norms or

\footnotetext{
${ }^{2}$ This article is not a product of the Institute, $i d$., nor any of the delegates to the Institute. Rather, I have used my personal observation of the delegate reports as a springboard for my own inquiry. Any error here in reporting the law or facts of the European cases is mine alone.

${ }^{3}$ For readers interested in the original reports of the delegates or additional country reports not selected here for my thematic inquiry, the Institute, $i d$., annually publishes a European Tort Law Yearbook. See Institute for European Tort Law, European Tort Law Yearbook, http://www.ectil.org/etl/Publikationen/Yearbook-on-European-Tort-Law.aspx [http://perma.cc/JST4-VHKW] (last visited July 9, 2015).
} 
democratic initiatives. The article concludes third that when public liability is at issue, the recent European decisions consistently exhibit willingness to embrace plaintiffs' causes as against the state. The European courts seem more disposed than the U.S. courts to realize judicial preeminence in the constitutional field, perhaps for reason of legal- and socio-historical differences.

For all the differences in legal traditions between the United States and Europe, between American federalism and EU hybrid federalism, and between common law and predominantly civil code systems, the universal problem of tort proves transcendent of legal jurisdictions and political borders. As articulated by Professor Marshall Shapo:

"A injures B and could have avoided it. What should society do about it?"4

\section{REPORTED DEVELOPMENTS}

\section{A. LIFE, DEATH, AND DAMAGES}

Money for physical injury, and even for loss of life, is a central feature of civil justice in modern society, superseding the historic lex talionis. ${ }^{5}$ But affixing a number to physical loss is a dubious undertaking. And death cases especially lay bare the folly of trying to make a plaintiff whole, ${ }^{6}$ especially when considering the range of answers on offer in worker compensation law, environmental law, and wrongful-death litigation. ${ }^{7}$ Both the United States and Europe have favored corrective over retributive justice in tort, electing money to serve as proxy for loss. Yet after centuries of experience with this more civilized system, valuation remains a fog.

\footnotetext{
${ }^{4}$ Marshall S. Shapo \& Richard J. Peltz, Tort AND InJURy LAW 3 (3d ed. 2006).

${ }^{5}$ See, Code of Hammurabi II 196 (c.1850 B.C.) (Ancient Babylon). "Lex talionis" refers to the law of retaliation, also termed “eye for an eye.” BLACK's LAW DICTIONARY 1052 (Bryan A. Garner, ed., 10 ${ }^{\text {th }}$ ed. 2014). Cf., e.g., Leviticus 24:19-21.

${ }^{6}$ See generally Andrew J. McClurg, Dead Sorrow: A Story About Loss and a New Theory of Wrongful Death Damages, 85 B.U. L. REV. 1 (2005) (lamenting inevitable inadequacy of money obtained through litigation to compensate survivors for loss of loved ones, and proposing memorials and similarly more efficacious remedies alternatively).

${ }^{7}$ See, e.g., SHAPO \& PELTZ, supra note 4, at 407-08 (excerpting AM. BAR ASS'N, TOWARDS A JURISPRUDENCE OF INJURY 5-164 to -175 (1984) (Marshall S. Shapo, reporter)).
} 
Accordingly, valuation in cases of property damage, physical injury, death, and survival constituted a recurring theme in the European presentations. Valuation and the scope of consequential damages lay at the heart of the matter in reports from Estonia, Finland, Malta, and Slovakia. Related problems occurred in the reports from Belgium, Italy, and Portugal, which respectively implicated thorny policy problems in "wrongful life," the value of life per se, and parasitic damages in case of a loved one's extraordinary trauma.

\section{ESTONIA AND THE CASE OF THE FISHY CAR}

At issue in an Estonian case ${ }^{8}$ was whether the plaintiff's property damage warranted a replacement car to go fishing. ${ }^{9}$ The plaintiff lost the use of his high-end car (a BMW X5) after collision with a Tallinn tram that failed to give way to a traffic light. ${ }^{10}$ The plaintiff's damages included a temporary replacement vehicle for daily use, but the defense balked at the steep price tag: $€ 7100$ for 5.5 months' rental. ${ }^{11}$ The appellate court annulled the damages, opining that pecuniary damages should include only loss of "necessary or useful" activities, not pursuit of mere "hobbies," according to the statute. ${ }^{12}$ On remand, plaintiff, who held qualifications and permits to fish, ${ }^{13}$ was able to demonstrate that fishing was for him "economic or professional activities or work," ${ }^{14}$ so he recovered. ${ }^{15}$

\footnotetext{
${ }^{8}$ Riigikohus [Supreme Court] Civ. Chamber Oct. 27, 2014, No. 3-2-1-90-14 (Meier v. Tallinn Urb. Transp. Co.) (Estonia), http://www.nc.ee/?id=11\&tekst=RK/3-2-1-90-14 [http://perma.cc/39SS-VJA9] (translated to English by Google Translate).

${ }^{9}$ Irene Kull, Institute, supra note 1, Apr. 10, 2015 (Estonia).

${ }^{10}$ Meier, No. 3-2-1-90-14, IIII 1-2.

${ }^{11} I d$. 1 I 3 .

${ }^{12}$ Id II 14 (construing Law of Obligations Act $\S 132(4)$ (Estonia), available at https://www.riigiteataja.ee/en/eli/516092014001/consolide) (in original, "vajalik või kasulik" and "harrastustega").

${ }^{13} I d$.

${ }^{14} I d$. (in original, "tema majandus- või kutsetegevuseks").

${ }^{15}$ Kull, Institute, supra note 1.
} 
Tort law in the United States usually affords a plaintiff recovery for loss of use of a vehicle damaged or destroyed in an accident. The pleasure or commercial purpose of the vehicle may vary the basis for calculating the loss. Lost use of commercial property might be valued in terms of a rental replacement, or if replacement is impossible, of lost profits for want of the vehicle. ${ }^{16}$ Recovery for lost use without demonstrated commercial purpose usually, ${ }^{17}$ though not universally, ${ }^{18}$ also is allowed, whether as rental replacement or general damages. ${ }^{19}$ The Estonian court, construing the civil code, was more restrictive in its approach to consequential damages, requiring the plaintiff to show some degree of necessity for rental replacement. But the distinction between commercial and personal use is common to Estonia and the United States, if dispositive in the former and only to suggest the basis of valuation in the latter.

\section{FINLAND AND THE CASE OF THE MisSing EdUCATION}

At issue in a Finnish case ${ }^{20}$ was the quantum of damages for a student whose studies were delayed by injury. ${ }^{21}$ Faced with a physical confrontation, the student had been compelled to jump from a window, fracturing his spine and leg. ${ }^{22}$ With resulting chronic back pain, the plaintiff discontinued his studies for an academic year and was unable to work for almost two years. ${ }^{23}$ The lower courts had disagreed about the calculation of lost earnings under the tort liability statute,

\footnotetext{
1622 AM. JuR. 2d Damages $\S 309$ (WestlawNext database updated May 2015).

${ }^{17}$ E.g., Parilli v. Brooklyn City R.R., 236 A.D. 577, 578, 260 N.Y.S. 60, 62 (App. Div. 1932) ("loss of use of a pleasure car").

${ }^{18}$ E.g., Hardy v. National Mut. Casualty Co., 9 So. 2d 346, 349 (La. Ct. App. 2d Cir. 1942) (disallowing loss-of-use damages for want of evidence).

${ }^{19}$ E.g., Lonnecker v. Van Patten, 179 N.W. 432, 433 (Iowa 1920) ("reasonable value of the use of said car during the time it was reasonably necessary to make the repairs on the same"); see also Pittari v. Madison Ave. Coach Co., 188 Misc. 614, 616, 68 N.Y.S.2d 741, 742-43 (City Ct. 1947) (allowing recovery predicated on rental replacement even though plaintiff did not hire replacement).

20 Korkein Oikeus [Supreme Court] Dec. 19, 2014, No. KKO:2014:97 (Fin.), http://www.finlex.fi/fi/oikeus/kko/kko/2014/20140097 [http://perma.cc/8NP2-K5ZY] (translated to English by Google Translate).

${ }^{21}$ Päivi Korpisaari, Institute, supra note 1, Apr. 10, 2015 (Finland).

${ }^{22}$ No. KKO:2014:97 (background).

${ }^{23}$ Id. (background).
} 
specifically whether compensation should derive from plaintiff's loss of productive time in a future profession, even though he had not yet graduated university at the time of the accident. ${ }^{24}$ The trial court awarded heavier compensation, $€ 42,543$ for lost professional opportunity (less $€ 7296$ paid from social insurance), but the intermediate appellate court reduced the award to $€ 12,743 .^{25}$ Restoring the larger award, the Supreme Court concluded that lost earnings should derive from "delay in access to the profession," because expected earnings over a career are diminished. ${ }^{26}$ The award is subject, however, to the usual principles that plaintiff must prove causation and must mitigate loss. ${ }^{27}$

Cases involving the permanent disability or death of a child in the United States raise difficult valuation problems because of the need to speculate about numbers such as hypothetical lifetime earnings. Nevertheless, such valuations are done, and in a less speculative vein, a college student whose graduation is delayed by injury may claim lost earnings for the period of delayed entry into the workforce. ${ }^{28}$ Of course, the damages must be proved to the usual standard of reasonable certainty, and plaintiffs are not always able to do so. ${ }^{29}$ The U.S. and Finnish approaches accord on this point.

\footnotetext{
${ }^{24} I d$. at 3.

${ }^{25} I d$. (background).

${ }^{26} I d$. at 8-9, 11, 21 (construing Damages Act $§ 2 \mathrm{a}$ (Fin.)).

${ }^{27}$ Id. at $14,19$.

${ }^{28}$ Martino v. Sunrall, 619 So. 2d 87, 90 (La. Ct. App.), writ denied sub nom. Martino v. Sumrall, 621 So. 2 d 821 (La. 1993).

${ }^{29}$ Branan v. Allstate Ins. Co., 761 So. 2d 612, 614, 616 (La. Ct. App. 5 Cir. 2000) (doubting that plaintiff, who took 15 years to earn undergraduate degree with " "poor"” academic record, would have attained master's degree as he alleged).
} 


\section{Malta AND the CASE OF THE Disfigured HomeMaKeR}

A Maltese case ${ }^{30}$ tackled the socially fraught problem of quantifying compensation for the pecuniary and psychological losses of a plaintiff-homemaker injured by a cosmetic medical procedure. ${ }^{31}$ The plaintiff sought pulsed dye laser treatment for vascular lesions on her face. ${ }^{32}$ The doctor being away from the office, the treatment was administered by a negligent technician, who set the laser to too strong a power. ${ }^{33}$ Plaintiff suffered burns and disfigurement, "multiple flat perfectly round white areas (each 7 millimeters in diameter) distributed across both cheeks and the bridge of the nose," made more apparent by contrast with the already existing red blood vessels. ${ }^{34}$ An expert quantified the disfigurement at " $3 \%$ permanent disability." 35 At issue was the quantum of damages; the plaintiff complained of psychological suffering that far outstripped the pecuniary cost of remedial cosmetics. The lower court had pointed to human rights norms in the Maltese Constitution, the European Convention for the Protection of Human Rights and Fundamental Freedoms, and the Charter of Fundamental Rights of the European Union to ground a $€ 5000$ award for injury to "psycho-physical integrity of the person." 36

The appellate court disagreed on the rationale, finding no application for EU human rights norms in a domestic civil dispute. ${ }^{37}$ Nevertheless, the court upheld the damages award of $€ 5000$ under the Maltese Civil Code as a form of "loss of future earnings."38 The court quoted 1997

\footnotetext{
${ }^{30}$ Qorti tal-Appell [Court of Appeal] June 27, 2014, Civ. App. No. 2429/1998/1 (Malta) (Cordina né Bussutil v. Muscat), http://www.justiceservices.gov.mt/courtservices/Judgements/search.aspx?func=all [http://perma.cc/VY9QDLVD ] (registration no. 2429/1998/1) (translated to English by Google Translate).

${ }^{31}$ Giannino Caruana Demajo, Institute, supra note 1, Apr. 10, 2015 (Malta).

${ }^{32}$ Civ. App. No. 2429/1998/1 (background).

${ }^{33} \mathrm{Id}$. (background and quoting lower court decision IIII 18, 40).

${ }^{34} \mathrm{Id}$. (quoting lower court decision III 13, 16, 51).

${ }^{35} \mathrm{Id}$. (quoting lower court decision II 14 (quoting expert testimony)).

${ }^{36}$ Id. (quoting lower court decision II 60) (in original, "[1]-integrità psiko-fiżika tal-persuna").

${ }^{37}$ Civ. App. No. 2429/1998/1 (court opinion).

${ }^{38}$ Id. (court opinion) (construing Civ. Code art. 1045(1) (Malta)) (in original, “ghal telf ta' qliegh futur”).
} 
precedent (with gendered terms): "Housework has economic value, and the contribution that the lady of the house gives to the domestic economy should not be considered to be less than the man's." "39 The court calculated that the national minimum wage, an annual $€ 10,500$, multiplied by $3 \%$ permanent disability, and multiplied by 16 years' remaining work-life for the 48 -year-old plaintiff, resulted in an award conveniently approximate to $€ 5000 .^{40}$ The Maltese delegate characterized the case as "a missed opportunity" to recognize non-pecuniary damages in civil liability. ${ }^{41}$

The default rule of U.S. tort law being to value a person in terms of his or her economic productivity, U.S. courts too have struggled to value homemaking fairly (at least since modern recognition of gender equality). Typically homemaking is subject to valuation by the jury, and the question may occasion expert testimony. ${ }^{42}$ In this sense, the effort at valuation is common to Malta and the United States. The U.S. finder of fact, taking a replacement-cost approach, is likely to arrive at a number consistent with low-wage labor. (That that number hardly reflects the opportunity cost of a spouse's career works an injustice, but an injustice common to both systems.) ${ }^{43}$ U.S. case law reflects an additional process, as a jury award for homemaking services may be analyzed for adequacy or excess. ${ }^{44}$ The United States diverges from Malta, however, in

\footnotetext{
${ }^{39}$ Id. (court opinion) (quoting Malta Civ. Ct. 1st Hall Feb. 21, 1997 (Grech v. Briffa)) (in original, "xoghol tad-dar ghandu valur ekonomiku, u l-kontribut li taghti l-mara taddar lill-ekonomija domestika ma ghandux jitqies li huwa anqas minn tar-ragel").

${ }^{40}$ Id. (court opinion).

${ }^{41}$ Caruana Demajo, Institute, supra note 1.

42 22A AM. JUR. 2D Death $\S 344$ (WestlawNext database updated May 2015).

${ }^{43}$ Frances Jean Pottick, Tort Damages for the Injured Homemaker: Opportunity Cost or Replacement Cost?, 50 U. COLO. L. REV. 59, 59-61 (1978) (concluding that in light of increasing number of women forced to choose between career and full-time homemaking, opportunity-cost approach more fairly assesses value of services than market-based replacement-cost approach).

44 See generally 47 A.L.R.4TH 100 (originally published 1986) (cataloging awards in homemaker-death cases as excessive or not, and adequate or not, classified according to family circumstances of homemaker).
} 
that there is no U.S. constitutional norm of personal integrity that underpins personal-injury compensation.

\section{Slovakia AND the CASE OF THE SPOILED Social LiveS}

The Slovak Supreme Court ${ }^{45}$ held that both a plaintiff injured in a serious car accident and her spouse were entitled at least to lay claims for non-pecuniary damages for impairment of their social lives and for interference with their private lives regardless of the injured plaintiff's pain. ${ }^{46}$ The Slovak civil code governing personal injury plainly allowed the injured plaintiff to lay claims for both pain and social impairment. ${ }^{47}$ Social losses account for "restriction on the full participation of the victim in personal and family, social, political, cultural and sporting life," as well as "direct compromise [to] the performance or choice of profession, choice of future life partner, [or] possibility of further self-education." ${ }^{48}$ The injured plaintiff and her husband also could lay claims under the law of privacy, namely the civil code provision that "confers on every individual [the] right to privacy, particularly life and health, civil honor and human dignity."49

However, plaintiff's husband might not have alleged facts sufficient to support his claim.

The intermediate appellate court had aptly explained that,

the right to appropriate financial compensation is reserved for those cases where the intensity of interference in private and family life of the person concerned is substantial and irreparable, for example, in the event of the death of a loved one, a

45 Najvyšší Súd [Supreme Court] May 28, 2014, $\quad$ No. $7 \quad$ Cdo $\quad 65 / 2013 \quad$ (Slovk.), http://www.supcourt.gov.sk/data/att/38289_subor.pdf [http://perma.cc/Z3ZD-8VLU] (translated to English by Google Translate) (construing Civ. Code $\S \S 11-13$ (Slovk.)).

46 Anton Dulak, Institute, supra note 1, Apr. 10, 2015 (Slovakia).

${ }^{47}$ No. 7 Cdo 65/2013 (construing Civ. Code $\$ 444$ (Slovk.)).

${ }^{48} I d$. (in original, "Pod st’ažením spoločenského uplatnenia treba rozumiet' jednak vylúčenie či obmedzenie účasti poškodeného na plnom osobnom a rodinnom, spoločenskom, politickom, kultúrnom a športovom živote, jednak st'aženie či dokonca priamo znemožnenie výkonu či vol'by povolania, vol'bu budúceho životného partnera, resp. možnosti d'alšieho sebavzdelávania.").

${ }^{49} I d$. (construing Civ. Code $\S 11$ (Slovk.)) (in original, “Občiansky zákonník v ustanovení § 11 priznáva kaţdej fyzickej osobe právo na ochranu osobnosti, najmä ţivota a zdravia, občianskej cti a l'udskej dôstojnosti, ako aj súkromia, svojho mena a prejavov osobnej povahy."). 
serious or persistent disruption of family ties, or, in the case of serious consequences for life. ${ }^{50}$

The plaintiff's husband seemed to have endured only "transient impact"51 during his wife's recovery, a leisure-opportunity cost comfortably within the non-compensable "scope of mutual rights and obligations inherent in wedlock."52

Some U.S. courts balk at distinguishing loss-of-enjoyment-of-life damages from pain and suffering for fear of permitting double recovery. ${ }^{53}$ However, many U.S. courts have permitted recovery for lost social opportunity as a form of hedonic damages in tort. ${ }^{54}$ Notwithstanding some courts' hypersensitivity to the evil of double recovery, the Slovak and U.S. approaches accord in recognizing social impairments as consequential damages. The Slovak insistence on a degree of severity moreover accords with the U.S. aversion to compensation for purely emotional suffering without a clear evidentiary basis. However, the countries diverge, in that, again, there is no civil right of privacy or personal integrity to ground recovery in common law tort.

\section{Belgium And the CASE of the Late Prenatal Diagnosis}

The Belgian Court of Cassation ${ }^{55}$ found itself presented with the very thorny question of whether to compensate a plaintiff for so-called "wrongful birth," or "wrongful life."56 A gynecologist failed to inform plaintiff-parents of a positive prenatal test at 16 weeks, indicating

\footnotetext{
${ }^{50} I d$. (in original, "právo na primerané finančné zadost'učinenie je vyhradené pre tie prípady, ked' intenzita zásahu do súkromného a rodinného života dotknutej osoby je značná a nenapravitel'ná, napr. v prípade smrti blízkej osoby, vážneho alebo pretrvávajúceho narušenia rodinných väzieb, alebo v prípade vážnych doživotných následkov").

${ }^{51} I d$. (in original, "prechodnému vplyvu").

${ }^{52}$ No. 7 Cdo 65/2013 (in original, “z rozsahu vzájomných práv a povinností, ktoré sú vlastné manželskému zväzku").

${ }^{53}$ See e.g., Loth v. Truck-A-Way Corp., 60 Cal. App. 4th 757, (Cal. Ct. App.1998) (ruling distinct jury instructions as prejudicial for fear of double recovery).

${ }^{54}$ See e.g., Cormier v. Republic Ins. Co., 118 So. 3d 16, 20 (La. Ct. App. 2012) (recognizing impact of hearing impairment on social life).

${ }^{55}$ Hof van Cassatie [Court of Cassation] Nov. 14, 2014, No. C.13.0441.N (B.D. v. W.C.) (Belg.), http://justice.belgium.be/fr/binaries/C_13_0441_N_tcm421-259179.pdf [http://perma.cc/2BQT-A4LQ] (translated to English by Google Translate).

${ }^{56}$ Isabelle C. Durant, Institute, supra note 1, Apr. 10, 2015 (Belgium).
} 
spina bifida. ${ }^{57}$ The child was subsequently born with severe physical limitations, including limited mobility, a brain abscess, and mental disability. ${ }^{58}$ The parents, who were informed of the danger later, at 33 weeks, claimed a missed opportunity to terminate the pregnancy, and the lower courts discounted that claim to an $80 \%$ probability of termination. ${ }^{59}$ Referencing a child's right to life as articulated in the International Covenant on Civil and Political Rights, the Convention on the Rights of the Child, and the European Convention for Protection of Human Rights and Fundamental Freedoms, the court concluded that the civil code could not be read to authorize an award based on a probability of abortion. ${ }^{60}$ The Court of Cassation authorized damages insofar as injury to the child resulted from medical negligence in failure to timely diagnose the child's condition. ${ }^{61}$ But the court rejected damages insofar as they were based on "a comparison [of the child's existing life] ... with a state of non-existence." ${ }^{\prime 62}$

Regarding damages as impossibly speculative, and asserting a host of public policy reasons, the vast majority of U.S. jurisdictions reject causes of action for "wrongful birth" or "wrongful death." ${ }^{\prime 3}$ Judges of all political persuasions are loath to characterize a child's life as a form of "damage" in tort. Indeed, regardless of political and moral stances on abortion, courts are reluctant to encourage the inference of the successful tort action that abortion necessarily would have been the preferable, "reasonable" alternative to the extant child ${ }^{64}$ In this sense, the Belgian and the U.S. approaches accord. They also suffer from the same potential shortcoming, which is

\footnotetext{
${ }^{57}$ No. C.13.0441.N (quoting intermediate appellate court opinion I[ 1.2).

${ }^{58} I d$. (quoting intermediate appellate court opinion II 1.6).

${ }^{59} \mathrm{Id}$. (quoting intermediate appellate court opinion II 1.3.2).

${ }^{60} I d$.

${ }^{61}$ Id. (judgment II 7) (construing Civ. Code arts. 1382-1383 (Belg.)).

${ }^{62}$ No. C.13.0441.N (judgment II 8) (in original, "een vergelijking moet worden gemaakt met een toestand van nietbestaan").

${ }^{63}$ Wendy F. Hensel, The Disabling Impact of Wrongful Birth and Wrongful Life Actions, 40 HARV. C.R.-C.L. L. REV. 141, 160-62 (2005) (citing California, New Jersey, and Washington as exceptional).

${ }^{64}$ Deana A. Pollard, Wrongful Analysis in Wrongful Life Jurisprudence, 55 ALA. L. REv. 327, 328-329 (2003).
} 
that a medical malpractice recovery that does not assume abortion in the hypothetical alternative, is highly unlikely to account for the lifelong costs - pecuniary and non-pecuniary-that a plaintiff family will have to bear (though European social welfare is likely to help out more than the U.S. safety net) ${ }^{65}$ In this sense, both systems shortchange plaintiffs by confining the analysis to medical malpractice.

\section{ITALY AND THE CASE OF THE LOST LiFE}

The Italian courts ${ }^{66}$ confronted a claim for life-per-se damages in a tragic case arising from a fatal car accident ${ }^{67}$ In that case, Giuliana Panzavolta died three hours after she suffered injuries in a car accident. ${ }^{6}$ The plaintiffs, family of Panzavolta and her husband, Marcello Sopranos, alleged that as a result of Panzavolta's death, Sopranos suffered from depression and committed suicide two years later. ${ }^{69}$ In Italy, heirs are entitled at law to recover for "moral suffering" that occurs between a loved one's injury and death while the person "remained lucid and conscious" for "an appreciable time." ${ }^{70}$ However, since 2008 the courts have construed the civil code to allow no recovery for non-pecuniary "biological damages." Rather, counts allow recovery only for pecuniary loss, in cases of immediate or nearly immediate death. ${ }^{71}$ The lower courts both compensated the plaintiffs with bereavement damages ("iure proprio") for death, as well as painand-suffering and physical-injury damages (the latter, "danno biologico") for Sopranos's death. ${ }^{72}$

\footnotetext{
${ }^{65} I d$. at $352-366$.

66 Corte di Cassazione [Court of Cassation] Mar. 4, 2014, No. 5056 (Massaro v. d'Urso) (It.), http://www.foroitaliano.it/cass-ord-4-marzo-2014-n-5056-e-sent-23-gennaio-2014-n-1361-i-719-natura-del-dannonon-patrimoniale-e-danno-tanatologico/ [http://perma.cc/KJK7-ZR84] (translated to English by Google Translate).

${ }^{67}$ Elena Bargelli, Institute, supra note 1, Apr. 10, 2015 (Italy).

${ }^{68}$ No. 5056 (part II).

${ }^{69} \mathrm{Id}$. (part II).

${ }^{70}$ Id. II 4 (in original, "sofferenza morale" and "sia rimasta lucida e cosciente"), If 5 (in original, "un tempo apprezzabile").

${ }^{71}$ Id. II 5 (in original, "danno biologico").

${ }^{72}$ Bargelli, Institute, supra note 1.
} 
But the courts denied recovery for Panzavolta's pain and suffering, as well as biological damage in loss of life. ${ }^{73}$

On appeal, the Italian Court of Cassation found that precedent supported moral damages upon mere hours of pain and suffering, which illustrated that the lower courts erred. ${ }^{74}$ More importantly, though, the court reversed direction on "thanatological damages" ("danno tanatologico"), or damages for loss of life per se. ${ }^{75}$ The court found "incongruity" in the rejection of loss-of-life damages, considering the primacy of the right to life itself over the distinguishable right to health. ${ }^{76}$ It should not be, the court reasoned, "“economically more "convenient" to kill than to hurt." ${ }^{, 77}$ Moreover, loss-of-life damages serve to signal to society the wrongness of killing and accordingly serve the deterrence function of the tort system.

Of interest to the American reader, the Italian court quoted with approval a 1987 federal case from Illinois, in which U.S. District Judge Leighton approved the use of expert testimony to establish for a jury "the hedonic value of the life . . taken."78 The Italian court quoted economist Stanley Smith's definition for the jury of "hedonic," which "refers to the larger value of life, the life at the pleasure of society, if you will, the life - the value including economic, including moral, including philosophical, including all the value with which you might hold life."79 Thus, loss of life is now compensable in Italy regardless of a victim's knowledge of impending death, regardless

\footnotetext{
${ }^{73} I d$.

74 No. 5056.

${ }^{75} \mathrm{Id}$.

${ }^{76} I d$. (in original, "incongruenze").

${ }^{77}$ Id. (quoting earlier case law) (in original, "“economicamente più "conveniente" uccidere che ferire"”).

${ }^{78}$ Sherrod v. Berry, 629 F. Supp. 159, 160 (N.D. Ill. 1985), rev'd on other grounds, 856 F.2d 802 (7th Cir. 1988). Painfully apropos of current events in 2015, Sherrod was a civil rights case arising from the police shooting of an innocent, 19-year-old African-American man in Joliet, Illinois, in 1979. Id. at 160-62.

${ }^{79}$ Id. at 163, quoted in No. 5056 (in original, “e il 'danno edonistico' (figura quest'ultima di diritto americano, concernente il 'più ampio valore della vita,' comprendente 'il profilo economico, quello morale, quello fisiologico; insomma (a) tutto il valore che si può attribuire alla vita' ...)”).
} 
of the intensity of suffering, and regardless of whether an "appreciable time" elapsed between injury and death. ${ }^{80}$ Furthermore, the recovery is inheritable. ${ }^{81}$ However, these questions are now on further appeal. ${ }^{82}$

Reliance on the federal decision from Illinois was ironic, because U.S. courts generally reject damages for life per se in case of instant death, absent conscious pain and suffering, or at least knowledge of impending death. ${ }^{83}$ The lower courts' handling of the Panzavolta-Sopranos claims accords with the vast-majority approach in the United States. Additionally, U.S. courts are unlikely to follow the lead of the court of cassation. Indeed, the U.S. hypersensitivity to double recovery would find distasteful a seemingly standardless inquiry into the value of life per se when it is allowed to persist alongside other death damages, such as suffering before death and familial loss of consortium. Furthermore, most states already define consortium to exclude bereavement. ${ }^{84}$ Therefore, if the Italian court's new direction stands, it will mark a point of divergence from both U.S. and Italian precedent.

\footnotetext{
${ }^{80}$ No. 5056.

${ }^{81} \mathrm{Id}$.

${ }^{82}$ Bargelli, Institute, supra note 1; see also Paolo Russo, Il Danno non Patrimoniale da Perdita del Congiunto Spetta Anche ai Fidanzati, QUOTIDIANO GIURIDICO, Apr. 2015, http://www.quotidianogiuridico.it/Civile/il_danno_non_patrimoniale_da_perdita_del_congiunto_spetta_anche_ai_fi danzati_id1168531_art.aspx [http://perma.cc/DD9Z-GC7A] (confirming ongoing pendency of appeal); Rivoluzionaria Pronuncia della Corte di Cassazione sul Danno da Morte Immediata (cd Danno Tanatologico), STUDIO LEGALE LDS, Feb. 17, 2015, http://www.studiolegalelds.it/rivoluzionaria-pronuncia-della-corte-dicassazione-sul-danno-da-morte-immediata-c-d-danno-tanatologico/ [http://perma.cc/B246-7LCL] (reporting case and appeal).

831 Jacob A. Stein, Stein on Personal InJury Damages Treatise $§ 3: 58$ (3d ed. 2015).

${ }^{84}$ E.g., 1 Marc G. Perlin \& Davalene Cooper, Massachusetts Proof of Cases Civil $\$ 33: 71$ (2014) (citing Mass. Gen. L. ch. 229, § 2).
} 


\section{Portugal AND the CASE OF THE Suffering SpOUSE}

Further testing this line between death and near-fatal injury, a Portuguese case ${ }^{85}$ contemplated parasitic spousal recovery in case of a victim's traumatic injury and permanent disability. ${ }^{86}$ In this case, a garbage collector struck by a vehicle suffered horrifically. His injuries including brain trauma, blunt chest trauma, leg amputation, and renal failure, all amounting to more than 10 months' hospitalization and $80 \%$ permanent disability, as well as consequent posttraumatic stress and depression. ${ }^{87} \mathrm{He}$ will forever need personal assistance to bathe, dress, and travel from his home. ${ }^{88}$ At issue was the parasitic recovery of his wife, anguished by her husband's suffering and change in character, deprived of consortium, and burdened with his care ${ }^{89}$ Had the man been killed, the law would have provided bereavement recovery for the surviving spouse. But the Code does not authorize recovery for a spouse's suffering when the victim survives. ${ }^{90}$ That approach was an intentional election by legislators when the civil code entered force in $1967 .{ }^{91}$

At the same time, the civil code empowers the appellate courts to harmonize the law. ${ }^{92}$ The court examined various European authorities, including European Law Principles of Civil Responsibility, which recognize, "[i] n cases of death or very serious injury," the possibility of “"compensation for non-material damage to persons who have a close relationship with the injured

\footnotetext{
85 Supremo Tribunal de Justiça [Supreme Court of Justice] Jan. 16, 2014, No. 6430/07.0TBBRG.S1 (Port.), http://www.dgsi.pt/jstj.nsf/954f0ce6ad9dd8b980256b5f003fa814/7bc174e495442fb180257cd8005c93a9?OpenDocu ment [http://perma.cc/5FU3-ZP3Z] (translated to English by Google Translate).

${ }^{86}$ André Pereira, Institute, supra note 1, Apr. 10, 2015 (Portugal).

${ }^{87}$ No. 6430/07.0TBBRG.S1, II III-VI.

${ }^{88}$ Id.at 31 .

${ }^{89} \mathrm{Id}$. at 8.

${ }^{90}$ See id. IIII 12-14.

${ }^{91}$ Pereira, Institute, supra note 1.

${ }^{92} \mathrm{Id}$.
} 
party. ${ }^{, 93}$ The court furthermore observed that approach in the laws of Spain, Italy, and Germany. ${ }^{94}$ Accordingly, the court confessed its intent to diverge from strict construction of the Portuguese code: "One can even say that the idea of evolution in time is particularly dear to all authors who have addressed the interpretation of the laws." 95 Re-construing the civil code, the court authorized recovery for "personal injuries, particularly severe, suffered by the spouse of [a] surviving victim, hit in a particularly hard way," and affirmed a $€ 15,000$ award to the plaintiff spouse. ${ }^{96}$ The Portuguese delegate moreover read the decision as not necessarily limited to spousal recovery. ${ }^{97}$ He characterized the change as "a turning point in Portuguese tort law" and a move in the direction of European norms. ${ }^{98}$

A victim's spouse in the United States is entitled to loss-of-consortium damages, usually compensating pecuniary and non-pecuniary losses for the services of the injured spouse. ${ }^{99}$ Again however, courts jealously guard the line against a spouse's recovery for grief and emotional suffering, fearing that such recovery would unduly double that of the injured party's award for pain and suffering. ${ }^{100}$ At first blush, then, the U.S. rule for a spouse's parasitic recovery is consistent, if unfortunate; whether the victim dies or survives, the spouse is not compensated for suffering. ${ }^{101}$ But closer scrutiny reveals some inconsistency. Some states-Florida, Louisiana,

\footnotetext{
${ }^{93}$ No. 6430/07.0TBBRG.S1, II 19 (in original, “'Nos casos de morte e de lesão corporal muito grave, pode igualmente ser atribuída uma compensação pelo dano não patrimonial às pessoas que tenham uma relação de grande proximidade com o lesado."') (quoting European Law Principles of Civil Responsibility art. 10:301).

${ }^{94}$ Id. II 20.

${ }^{95}$ Id. II 23 (in original, "Pode-se mesmo dizer que a ideia de evolução no tempo é particularmente querida a todos os Autores que se debruçam sobre a interpretação das leis.").

${ }^{96}$ Id. II 28 (construing Civ. Code art. 483, § 1, \& art. 496, § 1 (Port.)) (in original, "os danos não patrimoniais, particularmente graves, sofridos por cônjuge de vítima sobrevivente, atingida de modo particularmente grave").

${ }^{97}$ Pereira, Institute, supra note 1.

${ }^{98} I d$.

991 JACOB A. STEIN, STEIN on Personal Injury Damages § 3:58 (3d ed. 2015).

${ }^{100}$ E.g., Bailey v. Wilson408, 111 S.E.2d 106, 109 (Ga. Ct. App. 1959).

${ }^{101}$ E.g., 1 MASSACHUSETTS PROOF OF CASES CIVIL \$ 33:71 (WestlawNext database updated Dec. 2014) (citing Mass. Gen. L. ch. 229, § 2)). See generally M.C. Dransfield, "Sentimental” Losses, Including Mental Anguish, Loss
} 
South Carolina, Virginia, and West Virginia-do allow recovery for bereavement in death actions. ${ }^{102}$ And a small number of state death cases, if dated, have found their way to recovery for a decedent-spouse's "attention" and "care," regarding that loss as pecuniary and somehow distinguishable from the disallowed recovery for "the suffering which the one who is left endures."103 The significant number of situations in which death cases stretch the notion of pecuniary recovery to consider emotional factors raises the specter of inconsistency that came into being in the Portuguese case of severe injury. ${ }^{104}$ At least in states in which statutory wrongful death is more generous than common law personal injury, courts might be inclined to evolve the common law. The U.S. common law provides flexibility comparable to the harmonization norm of the Portuguese civil code.

\section{B. MultiPle Liabilities}

American states in the latter 20th century moved away from historic absolutes such as contributory negligence doctrine and plaintiff's choice in joint-and-several recovery. Doctrines of comparative fault, contribution, and sometimes even several-only recovery raise myriad challenges in contemporary multiple-liability scenarios, especially when common law rules such as active-passive indemnity persist alongside reforms. Common law evolutions and statutory revisions both generate ample questions for judicial interpretation, so the difference between precedent and code matters little in application. Such problems of interpretation in multiple

\footnotetext{
of Society, and Loss of Marital, Filial, or Parental Care and Guidance, as Elements of Damages in Action for Wrongful Death,74 A.L.R. 11, § V(a) (originally published 1931) (summarizing cases).

102 M.C. Dransfield, "Sentimental" Losses, Including Mental Anguish, Loss of Society, and Loss of Marital, Filial, or Parental Care and Guidance, as Elements of Damages in Action for Wrongful Death,74 A.L.R. 11, § IV(a) (originally published 1931) (Florida only in action by parents for death of child).

${ }^{103}$ Kountz v. Toledo, St. L. \& W.R. Co., 189 F. 494, 495 (Ohio C.C. 1908).

${ }^{104}$ Cf. Scott Korzenowski, Valuable in Life, Valuable in Death, Why Not Valuable When Severely Injured? The Need to Recognize A Parent's Loss of A Child's Consortium in Minnesota, 80 MinN. L. REV. 677, 684-89 (1996) (reporting, as exceptional, court awards for parent's loss of consortium upon minor child's severe disability, apparently predicated on injury to emotional edification of parent-child relationship).
} 
liabilities were implicated in the presentations of delegates from Germany, Greece, Ireland, Norway, and Slovenia.

\section{GeRMANY AND THE CASE OF THE UNUSED HELMET}

The line between corrective and distributive justice was sharply implicated in a German case $^{105}$ concerning contributory negligence in helmet non-use by a bicyclist. ${ }^{106} \mathrm{~A}$ bicyclist not wearing a helmet suffered traumatic brain injury after running into defendant's opened car door. ${ }^{107}$ The intermediate appellate court charged the bicyclist with $20 \%$ fault for not having worn a helmet, ${ }^{108}$ and the Federal Court of Justice recognized the "predominant view of the literature" that helmets mitigate head injury in bicycle collisions. ${ }^{109}$ However, the court observed that German helmet use is low, quoting $11 \%$ from a 2011 study, ${ }^{110}$ and that the federal legislature opted to encourage voluntary helmet use rather than to compel it. ${ }^{111}$ Under those circumstances, the court declined to charge the bicyclist with fault, ${ }^{112}$ lest the judiciary usurp the legislative prerogative. ${ }^{113}$

The "helmet defense" has come up more often in the United States in motorcycle accident cases. U.S. courts have divided over whether failure to wear a helmet can signify plaintiff's contributory fault when the legislature had not required helmets. The Wisconsin Court of Appeals, for example, held that the plaintiff's negligence for failing to wear a helmet was a question of fact

105 Bundesgerichtshof [BGH] [Federal Court of Justice] June 17, 2014, No. VI ZR 281/13 [Ger.], https://dejure.org/dienste/internet2?juris.bundesgerichtshof.de/cgi-

bin/rechtsprechung/document.py?Gericht=bgh\&Art=en\&nr=68287\&pos=0\&anz=1 [http://perma.cc/X374-B5RK] (translated to English by Google Translate).

106 Jörg Fedtke, Institute, supra note 1, Apr. 10, 2015 (Germany).

${ }^{107}$ No. VI ZR 281/13, II 1 (Ger.).

${ }^{108}$ Id. II 3.

${ }^{109}$ Id. II 15 (in original, "überwiegenden Auffassung der Literatur").

${ }^{110}$ Id. II 13.

${ }^{111} I d$. II 14.

${ }^{112}$ Id. II 15.

${ }^{113}$ Fedtke, Institute, supra note 1. 
properly submitted to the jury regardless of any statutory mandate or lack thereof. ${ }^{114}$ Plaintiff's failure to wear a helmet passed the evidentiary more-probative-than-prejudicial test, and the jury apportioned $10 \%$ fault to plaintiff. ${ }^{115}$ But the court remanded, opining that expert testimony was required for the jury to analyze the fault question. ${ }^{116}$ In contrast, the Supreme Court of Colorado held plaintiff's failure to wear a helmet inadmissible when the legislature had expressly repealed the state's helmet requirement seven years earlier. ${ }^{117}$ The court analogized to the same result upon a plaintiff's failure to wear a seatbelt. ${ }^{118}$ However, rather than pointing to the policymaking role of the legislature, the court proffered its own reasons for inadmissibility, including that the helmet question would precipitate an inefficient battle of experts, and a damages reduction would work an unmerited windfall for the plaintiff. ${ }^{119}$

In the fewer bicycle cases, plaintiff's failure to wear a helmet is often admitted only in mitigation of damages, even though the helmet decision is made prior to the accident. ${ }^{120}$ The mitigation approach — which is modestly anomalous because the plaintiff's helmet decision precedes the accident — might be an artifact of the pre-comparative fault era. A federal court analyzing New Jersey law decided that the failure of the legislature to require helmets for bicyclists over age 14 did not preclude the defense in case of the death of an adult plaintiff. ${ }^{121}$ The court considered state policy promoting voluntary helmet use and the state courts' approval of the

\footnotetext{
114 Oldakowski v. Heyen,428 N.W.2d 644,(Wis. Ct. App. 1988) (unpublished); see also Halvorson v. Voeller, 336 N.W.2d 118, 122 (N.D. 1983) ("Simply because our Legislature has chosen to not make it a traffic violation for a person 18 or over to operate or ride upon a motorcycle without wearing a helmet does not mean it intended that in the exercise of ordinary care a motorcyclist never may be expected to wear a helmet to avoid or mitigate injuries he may sustain in an accident.").

115 Oldakowski,428 N.W.2d at 2.

${ }^{116}$ Id. at 3.

${ }^{117}$ Dare v. Sobule, 674 P.2d 960, 962-63 (Colo. 1984).

${ }^{118}$ Id. at 962-63 (citing Fischer v. Moore,517 P.2d 458 (Colo. 1973)).

${ }^{119}$ Id. at 963.

12011 AM. JUR. PROOF OF FACTS 3D 503, §19 (1991).

${ }^{121}$ Nunez v. Schneider Nat'l Carriers, 217 F. Supp. 2d 562, 569 (D.N.J. 2002).
} 
seatbelt defense to allow the helmet defense to raise a question of fact in comparative fault for the jury. ${ }^{122}$ However, the court reported that the majority of courts across the country regard failure to wear a helmet as inadmissible "for assorted reasons," 123 and that approach in outcome, if not in rationale, accords with the German decision.

\section{GREECE AND THE CASE OF THE TWISTED KNEE}

In a Greek case, ${ }^{124}$ the plaintiff asserted the vicarious liability of a hospital for the medical malpractice of non-employee doctors. ${ }^{125}$ In January 2007, the plaintiff was injured in a motorcycle accident that was the fault of an unknown other driver. ${ }^{126}$ The plaintiff was evacuated to the codefendant hospital and treated for a twisted and abraded knee. ${ }^{127}$ In April, still in extreme pain after having returned to work, the claimant returned to the hospital and was diagnosed by a codefendant surgeon-orthopedist with a patellar fracture. ${ }^{128}$ Then in May, with the plaintiff experiencing chest pain, doctors at a different hospital determined that late diagnosis and inadequate preventive treatment of the fracture had resulted in a life-threatening blood clot (deep vein thrombosis) that had migrated to plaintiff's lungs (pulmonary embolism). ${ }^{129}$ The doctors of the first hospital were culpable; ${ }^{130}$ the salient point for the delegate from Greece was the vicarious liability of the hospital. ${ }^{131}$

\footnotetext{
${ }^{122} I d$. at $565,569$.

${ }^{123}$ Id. at 567.

124 Polymeles Protodikio Athinon [Pol. Pr.] [Athens Multi-Member Court of First Instance], 260/2014523 (Greece) (translated to English by Google Translate). I am grateful to Professor Eugenia Dacoronia for sharing with me a copy of this decision, which I have on file.

${ }^{125}$ Eugenia G. Dacoronia, Institute, supra note 1.

${ }^{126}$ No. 260/2014, at 526, 540.

${ }^{127} \mathrm{Id}$.

${ }^{128} \mathrm{Id}$. at $526,540$.

${ }^{129} \mathrm{Id}$. at 526, 535, 541-43.

${ }^{130} \mathrm{Id}$. at 530, 541-43, 551-52. The case was further complicated by claims and counterclaims, not material here, concerning contributory negligence, data protection law, and legal ethics. See id. at 543-48.

${ }^{131}$ Dacoronia, Institute, supra note 1.
} 
The Athens court held the hospital liable for the malpractice despite the lack of employment relationship with the doctors. ${ }^{132}$ The court found employment-like supervision in the hospital's provision of infrastructure, such as facilities, equipment, and drugs, the latter including the painkillers the plaintiff was prescribed and the anticoagulants he should have been prescribed but was not. ${ }^{133}$ Moreover, the court reasoned, the hospital derives profits from medical services, which are provided by doctors operating under common professional standards. ${ }^{134}$ And the hospital as a business benefits from the availability of doctors with a range of medical specializations, including orthopedics, in one place. ${ }^{135}$

Typically a hospital in the United States will not be vicariously liable for the medical malpractice of a non-employee professional, because vicarious liability usually arises from agency. ${ }^{136} \mathrm{~A}$ plaintiff in pursuit of the hospital therefore must fashion a theory of direct negligence in the hospital's administrative role, or through the hospital's supervision or retention of service providers. Nevertheless, some U.S. cases have allowed liability for the conduct of a non-employee doctor when the hospital evinced "ostensible agency," "creat[ing] or sustain[ing] the appearance" of an employment relationship. ${ }^{137}$ The Arizona Court of Appeals has developed a series of factors to test ostensible agency between a hospital and non-employee doctor: ${ }^{138}$ whether the patient was allowed to choose the doctor(s) that treated her; whether the hospital supplied equipment and staff to the doctor; whether there was a contract between the hospital and the doctor; whether the doctor

\footnotetext{
${ }^{132}$ No. 260/2014, at 550; Dacoronia, Institute, supra note 1.

${ }^{133}$ No. $260 / 2014$, at 550-51.

${ }^{134}$ No. $260 / 2014$ at 550.

${ }^{135}$ Id.; Dacoronia, Institute, supra note 1.

136 Dan B. Dobbs, Paul T. Hayden, \& Ellen M. Bublick, The Law of Torts $\S 316$ (2d ed.), WestlawNext (database updated June 2016).

${ }^{137} I d$.

${ }^{138}$ Barrett v. Samaritan Health Servs., Inc., 153 Ariz. 138, 146, 735 P.2d 460, 468 (Ct. App. 1987) (citing Beeck v. Tucson Gen. Hosp., 18 Ariz. App. 165, 500 P.2d 1153 (1972)).
} 
billed the patient directly or through the hospital; and whether the doctors had to follow hospital policies and regulations to retain staff privileges. ${ }^{139}$

This fact-intensive inquiry accords with the approach of the Athens court, which might gain from the articulation of factors.

\section{IRELAND AND THE CASE OF THE EMPTY CHAIR}

An Irish case ${ }^{140}$ delved into the weeds of liability apportionment. ${ }^{141}$ The claimant alleged abuse at St. John's National School in Sligo from 1969 to $1972 .{ }^{142}$ The suit was permitted by an extended statute of limitations. ${ }^{143}$ The court awarded the plaintiff $€ 350,000$ in general damages. ${ }^{144}$ Analyzing relative fault, the court assigned $90 \%$ fault to the defendant teacher, a brother of the Marist Order, who committed the abuse, and $10 \%$ fault to the school manager, whose authority over the Marist brothers was limited. ${ }^{145}$ Complicating matters, however, the school manager, Canon Collins, was an empty chair. He could not be sued, because action against him was timebarred—not subject to the extended limitations period—and Collins anyway had since died. ${ }^{146}$ The court gave the plaintiff no allowance on the empty-chair recovery; the plaintiff's award against the Marists was reduced by Collins’s $10 \%$ to $€ 315,000$.

Adult plaintiffs alleging child sex abuse in the United States also have met the challenges of statutes of limitation, whether through statutory extension of the limitations period or with a

\footnotetext{
139 Pollack v. Carondelet Health Network, No. C20014941, 2003 WL 25315324 (Ariz. Super. Ct. July 8, 2003) (unpublished trial order) (citing Barrett, 153 Ariz. 138, 735 P.2d 460 (Ct. App. 1987); Beeck v. Tucson Gen. Hosp., 18 Ariz. App. 165, 500 P.2d 1153, 1157-1158 (1972)).

${ }^{140}$ Hickey v. McGowan, [2014] IEHC 19 (H. Ct. Jan. 24, 2014) (Ir.), http://www.bailii.org/ie/cases/IEHC/2014/H19.html [http://perma.cc/9FKM-UWGN]

${ }^{141}$ Eoin Quill, Institute, supra note 1, Apr. 10, 2015 (Ireland).

142 Hickey, [2014] IEHC 19,I[ 1. The High Court found the claims incontrovertibly credible. Id. II 23.

${ }^{143}$ Quill, Institute, supra note 1.

${ }^{144}$ Hickey, [2014] IEHC 19, I[ 35.

${ }^{145}$ Id. II 75. The 90\% liability advanced furthermore against a second named defendant, the teacher's supervisor in the Marist Order, under ordinary principles of vicarious liability. Id. II 84.

${ }^{146}$ Id. II 54 (applying Civ. Liab. Act 1961, § 9(2) (Ir.)), II 76.
} 
tolling theory such as delayed discovery because of repressed memory or fraudulent concealment. ${ }^{147}$ Cases so delayed are bound to generate evidentiary problems, like the empty chair in comparative fault in the Irish case. California law was amended in 1990 to be more permissive of child sex-abuse claims, allowing them until the plaintiff's twenty-sixth birthday, and a court in 1994 ruled the extension inapplicable to "ancillary" negligence claims-respondeat superior, negligent hiring, and negligent supervision - against third parties to the abuse, namely the dance studio that employed the defendant instructor. ${ }^{148}$ Later, in 1998 and again in 2003, the legislature further relaxed the limitations period as to employers and supervisors. ${ }^{149}$

As to apportionment, U.S. courts in the comparative fault era have declined to effect liability allocation with intentional actors in the mix, because comparative fault is not a defense to intentional torts - though the Restatement (Third), Apportionment cracks the door open to such mixing. ${ }^{150}$ Nevertheless, once comparative fault is properly implicated, most U.S. courts include empty chair in apportionment. ${ }^{151}$ Shifting an empty chair's liability allocation to the plaintiff when the chair is empty because of the plaintiff's procedural constraints comports with the rule that only innocent plaintiffs are preferred in liability reallocations for absent parties. ${ }^{152}$

\footnotetext{
${ }^{147}$ Joseph M. Winsby \& Elaine D. Walter, Applying the Statutes of Limitations in Institutional Childhood Sex Abuse Cases, FlA. B.J., July/Aug. 2014, at 32.

${ }^{148}$ Debbie Reynolds Prof'l Rehearsal Studios v. Superior Court, 25 Cal. App. 4th 222, 230-231, 30 Cal. Rptr. 2d 514, 518 (1994) (citing CAL. CODE CIV. Proc. § 340.1).

${ }^{149}$ Perez v. Richard Roe 1, 146 Cal. App. 4th 171, 175, 52 Cal. Rptr. 3d 762, 764 (2006), as modified (Jan. 26, 2007) (citing CAL. CODE CIV. PROC. § 340.1).

${ }^{150}$ Frank J. Vandall, A Critique of the Restatement (Third), Apportionment As It Affects Joint and Several Liability, 49 EMORY L.J. 565, 606-607 (2000) (citing RESTATEMENT (THIRD) OF TORTS: APPORTIONMENT OF LIABILITY §§ 1, 8 (Proposed Final Draft (Revised), 1999)).

151 1 Comparative Negligence Manual $\S 14: 9$ (3d ed.), WestlawNext (database updated Mar. 2015) ("accepted practice in most jurisdictions").

${ }_{152}$ Vandall, supra note 149, at 580; see, e.g., Richter v. Presbyterian Healthcare Servs., 326 P.3d 50, 65 (N.M. Ct. App.), cert. denied, 326 P.3d 1111 (N.M. 2014) (under state comparative fault statute, allowing defendants to disclaim liability apportioned to nonparties exempt from liability to plaintiff by operation of statute of limitations).
} 


\section{NoRway AND THE CASE OF THE DRUNKEN DECEDENT}

A Norwegian case ${ }^{153}$ examined the comparative fault of plaintiffs' decedent. ${ }^{154}$ A test shortly after a fatal car accident showed the decedent to have been drunk with a blood-alcohol level of $0.166 \% .{ }^{155} \mathrm{He}$ was survived by his wife and unborn daughter, who conceded that their bereavement recovery should be reduced to account for the decedent's fault. ${ }^{156}$ At issue was the amount of the reduction. The trial court reduced recovery by a standard $50 \%$, and the intermediate appellate court revised the reduction downward to $30 \% .{ }^{157}$ The Supreme Court explained that Norwegian law historically charged survivors with the same reductions that the decedent would have suffered had he lived. ${ }^{158}$ The civil damages law and the motor vehicle law generally were in accord on that point. ${ }^{159}$

However, a Justice Committee in 1985 commented upon revision of the damages law that survivors' awards perhaps should not be reduced in full when doing so would work unfairness on the family of a negligent decedent. ${ }^{160}$ When the decedent was a family breadwinner, the court reasoned, the family's need for replacement income is "completely independent of the specific facts in connection with the fatal accident." 161 The deterrence rationale for a tort award is

153 Norges Høyesterett [Supreme Court] Nov. 12, 2014, No. HR-2014-2423-A (Nor.), http://unneland.as/nyheter/hoyesterettsdom_hr_2014_02423_a/content_1/text_cce429e5-b2ee-4df1-8207-

851a37f98132/1420625026128/hrsiv_avgjorelse_hr_2014_2423_a.docx (translated to English by Google Translate)[ http://perma.cc/83YM-JXLY].

${ }^{154}$ Knut Martin Tande, Institute, supra note 1, Apr. 10, 2015 (Norway).

${ }^{155}$ No. HR-2014-2423-A, II 2.

${ }^{156}$ Id. II 3.

${ }^{157}$ Id. III $4,6$.

${ }^{158}$ Id. III 19-20 (citing Crim. Code May 22, 1902, no. 11, § 25 (Nor.)). Comparative-fault reduction for plaintiffs dates to 1969. Id. II 21 (citing Damages Act June 13, 1969, no. 26, § 5-1 (Nor.)).

${ }^{159}$ Id. II 3 (comparing Automobile Liab. Act Feb. 3, 1961, § 7 (Nor.), with Damages Act June 13, 1969, no. 26, § 5-1 (Nor.)). The motor vehicle law explicitly contemplates attribution of fault to a claimant who knew of the driver's dangerous propensity. Id. III 24, 39. That scenario is not at issue on these facts, though its inconsistency with European law influenced the court's decision in a European direction. See id. III 43-44.

${ }^{160}$ Id. II 29.

${ }^{161}$ Norges Høyesterett [Supreme Court] Nov. 12, 2014, No. HR-2014-2423-A (Nor.), (quoting Justice Committee) (in original, "'helt uavhengig av de nærmere omstendigheter i forbindelse med dødsulykken"”). 
diminished when the responsible person has died, and, the committee reasoned, deterrence evaporates as a priority anyway when the award will be paid by insurance. ${ }^{162}$ Both the Justice Commission and the Parliament concluded that the "reasonable[ness]" rule of the damages act ${ }^{163}$ sufficiently contemplated a smaller reduction in award in appropriate circumstances. ${ }^{164}$ But neither commented specifically on the applicability of its logic to the motor vehicle law. ${ }^{165}$

Applying this rule of reasonableness, the court looked to European insurance law, which disfavors imputation of a decedent's fault to passengers, ${ }^{166}$ and to "the increased emphasis on social concerns within tort law." ${ }^{167}$ European law justified the intermediate appellate court's revision of reduction from $50 \%$ to $30 \%$, the latter a standard rate for surviving passengers. ${ }^{168}$ Changing social policy justified a focus on the needs of the survivors, especially in the context of a compulsory motor vehicle insurance system. ${ }^{169}$ Reasoning then that absent survivors could not be more culpable than extant passengers, the Supreme Court concluded that a $20 \%$ reduction would be more fitting for the claimants, who still must answer in some measure for the decedent, whose "action is equally reprehensible no matter who the claimants are." ${ }^{\prime 10}$ At the same time, the court found no ground to differentiate between spouse and child in the imputation of fault. ${ }^{171}$

A decedent's comparative fault in the United States similarly runs through statutory wrongful death claims to their beneficiaries. ${ }^{172}$ A downward modification based on social policy

\footnotetext{
${ }^{162} \mathrm{Id}$.

${ }^{163}$ Id. II 21 (quoting Damages Act June 13, 1969, no. 26, § 5-1 (Nor.)) (in original, "“rimelig"”).

${ }^{164}$ Id. TII 29, 33.

165 Id. II $29 ;$ see id. \I 33.

${ }^{166}$ Id. III 43-46.

167 Norges Høyesterett [Supreme Court] Nov. 12, 2014, No. HR-2014-2423-A (Nor.), 48 (in original, “den økte vektleggingen av sosiale hensyn innenfor erstatningsretten").

${ }^{168}$ Id. II 47.

${ }^{169}$ Id. III $51-53$.

${ }^{170}$ Id. TII 55-56 (in original, "hans handling er like klanderverdig uansett hvem som er skadelidt").

${ }^{171}$ Id. II 56. The intermediate appellate court had imputed $20 \%$ fault to the spouse and $10 \%$ to the child. Id. II 15.

172 DOBBS, HAYDEN, \& BUBLICK, supra note $136, \S 378$.
} 
with respect to survivors' needs would be highly unusual to result from judicial prerogative. There is the odd exception. When a truck driver killed in a highway accident was charged with $51 \%$ fault, the Iowa Supreme Court decided not to disallow or reduce his widow's claim under the wrongful death statute for loss of consortium. ${ }^{173}$ The court had previously refused to reduce spousal consortium recoveries with victim fault in personal-injury cases, also governed by statute, and saw no reason to treat wrongful death claims differently. ${ }^{174}$ The court explained: "The services, society, companionship, affection, and other elements of consortium are valuable and necessary ingredients of a satisfactory interspousal relationship. They are not, however, the kind of services the deprivation of which will give rise to a tort action between spouses."175

\section{Slovenia And the CASE OF The Dog that Bit the OWNER}

A Slovenian case ${ }^{176}$ presented a twisted problem of liability when a plaintiff was injured by her own dog. ${ }^{177}$ The plaintiff was a "young and beautiful girl," 27 years old, ${ }^{178}$ who was visiting her parents when the injury occurred. ${ }^{179}$ She herself was on record with the government vaccination registry as the owner of the dog, which had no known propensity for violence. ${ }^{180}$ She had left the dog under the "protection and supervision" of her parents, ${ }^{181}$ whom she sued, presumably to access their homeowner's insurance. ${ }^{182}$ Over the insurer's objection, the court

\footnotetext{
${ }^{173}$ Nichols v. Schweitzer, 472 N.W.2d 266, at 268, 272 (Iowa 1991).

${ }^{174}$ Id. at 271-72 (citing Schwennen v. Abell, 430 N.W.2d 98 (Iowa 1988)).

${ }^{175}$ Id. at 270 (quoting McIntosh v. Barr, 397 N.W.2d 516, 518 (Iowa 1986)).

176 Vrhovno Sodišče Civilni Oddelek [Supreme Court Civil Division] Feb. 20, 2014, Sodba [Judgment] No. II Ips 267/2011 (Slovn.), http://www.sodisce.si/znanje/sodna_praksa/vrhovno_sodisce_rs/2012032113066169/ (translated to English by Google Translate) [http://perma.cc/AFJ7-846L].

${ }^{177}$ Barbara Novak, Institute, supra note 1, Apr. 10, 2015 (Slovenia).

${ }^{178}$ No. II Ips 267/2011, II 11 (in original, "mlado in lepo dekle"). Professor Novak reported the plaintiff to be of age 17, Novak, Institute, supra note 1, which seems better consistent with the court's characterization of a "girl." Her age was relevant to damages. See text accompanying infra note 186.

179 No. II Ips 267/2011, II 1.

${ }^{180}$ Id. III 5-6, 9.

${ }^{181}$ Id. II 5 (in original, "varstvo in nadzorstvo").

182 See id. II 1.
} 
distinguished between the "owner" and "holder" of a dog, maintaining that the latter could bear liability to the exclusion of the former if the owner bore no fault. ${ }^{183}$ The Slovenian court further explained that categorical exclusion of dog owners from plaintiff status would offend equal protection under the Slovenian Constitution. ${ }^{184}$ The court, furthermore, affirmed an increase in the plaintiff's award for pain and suffering - the intermediate appellate court decided that the trial court had undervalued plaintiff's pain and suffering from disfiguring injury and raised that portion of the recovery from $€ 1900$ to $€ 7000^{185}$ _ opining that it is appropriate for the court to consider a plaintiff's subjective feelings of disfavor or inferiority based on the nature of the injury and her age. $^{186}$

The approach of the Slovenian court accords with U.S. law, which seeks to hold responsible the "keeper" of a dog_one who "exercise[s] care, custody, or control" "187_rather than necessarily the owner, even when a statute says "owner." 188 Who is the responsible keeper is a question of fact, and the parent of an absent owner may fit the bill. ${ }^{189}$ Inversely, one who "relinquishe[s] care, custody, and control" is not liable, notwithstanding legal ownership. ${ }^{190}$ So, there is no reason such a legal owner cannot be a plaintiff.

\footnotetext{
${ }^{183}$ Id. II 9 (construing Code of Obligations art. 158 (Slovn.)).

${ }^{184}$ Id. (citing Ustava [Constitution] art. 22 (Slovn.)).

${ }^{185}$ Id. II 3.

${ }^{186}$ Id. II 11.

${ }^{187}$ Spirlong v. Browne, 236 Ariz. 146, 151, 336 P.3d 779, 784 (Ariz. Ct. App. 2014).

${ }^{188}$ Armstrong v. Milwaukee Mut. Ins. Co., 202 Wis. 2d 258, 268, 549 N.W.2d 723, 728 (Wis. 1996) (construing WIS. STAT. § 174.02).

${ }^{189}$ E.g., Abraham v. Ibsen, 213 Ill. App. 210, 219-20 (Ill. App. Ct. 1919) (father of college student).

${ }^{190}$ Hayes v. Adams, 987 N.E.2d 402, 406 (Ill. App. Ct. 2013) (construing 510 ILCS 5/2.16 (West 1996)). But see Harris v. Anderson Cnty. Sheriff's Office, 381 S.C. 357, 366, 673 S.E.2d 423, 428 (2009) (strictly reading disjunctive strict liability provision of statute, S.C. CODE ANN. § 47-3-110 (“dog owner or person having the dog in the person's care or keeping is liable" (emphasis added)), to conclude that "a person injured by a dog may pursue a claim against the owner of the dog when the injury occurs while the dog is in the care or keeping of another").
} 


\section{INTERPLAY OF TORT AND INSURANCE}

Insurance often overshadows the civil liability system in Europe as in the United States, especially where motor vehicles are concerned. The presentations of delegates from Latvia and Spain focused on these interactions, as did a presentation on the law of the European Union.

\section{LATVIA AND THE CASE OF THE COMPANY CAR}

In a Latvian case, ${ }^{191}$ the court allowed civil liability for a defendant driver to the exclusion of the driver's insured employer. ${ }^{192}$ The defendant was driving a company car for the utility company AS Riga Heat when he violated criminal traffic law-seriously enough to win one to two years' imprisonment ${ }^{193}$ — and injured plaintiffs, two other drivers. ${ }^{194}$ AS Riga Heat held a compulsory third-party insurance policy on the company car. ${ }^{195}$ However based on the driver's criminal offense as establishing fault, only he was charged in the trial court award of damages in excess of $€ 8000$ for plaintiffs' non-pecuniary losses, including bodily injury, permanent scarring, and psychological trauma. ${ }^{196}$ With only the criminal defendant as natural person on the hook, plaintiffs faced the prospect of inability to enforce the judgment fully. ${ }^{197}$ Nevertheless, the Supreme Court ruled that neither the civil code nor the motor-vehicle insurance law authorized recovery against the insured owner of the company car. ${ }^{198}$ Two justices disagreed with the court's

\footnotetext{
${ }^{191}$ Augstākās Tiesas Civillietu Departamenta [Supreme Court Civil Department] Nov. 27, 2014, Lietā Nr. [Case No.] SKC-156/2014 (Lat.), http://at.gov.lv/files/files/skc-156-2014.doc (translated to English by Google Translate) [http://perma.cc/78PX-ZMEL].

192 Agris Bitāns, Institute, supra note 1, Apr. 10, 2015 (Latvia).

${ }^{193}$ No. SKC-156/2014, II 6.2.

${ }^{194}$ Id. . 1.

${ }^{195}$ Id. II 6.2.

${ }^{196}$ Id. IIIT 1.1, 1.3, 2.

${ }^{197}$ Bitāns, Institute, supra note 1.

${ }^{198}$ No. SKC-156/2014, III 6.1, 6.3 (construing Civ. Code $§ 2347$ (Lat.); Road Traffic Act art. 44 (Lat.); Motor Third Party Liab. Ins. Act (Lat.)). The insurer paid a modest indemnity of $€ 127$ for pecuniary medical losses. Id. II 6.3.
} 
decision; they wrote separately to lament that the court's reasoning rendered "vehicle third party liability compulsory insurance . . completely meaningless." 199

State vehicle insurance law varies widely in the United States, but the problem presented in the Latvian case unfortunately follows a known pattern. Automobile insurance policies typically exclude coverage from criminal conduct, and such provisions are straightforwardly enforceable in contract law with regard to losses of the insured. However, the matter is more complicated when third-party coverage is implicated because of the risk that an innocent party will go uncompensated in contravention of the purpose behind compulsory insurance requirements. Accordingly, an Illinois Appellate Court, upholding as "reasonable" a drunk-driving exclusion against the insured driver, observed that courts in other states "have been reluctant to apply criminal exclusions" as against "innocent victims of the criminals acts," thus "run[ning] afoul of the mandatory automobile liability insurance statutory provisions enacted in 47 states and the District of Columbia."200 Were that the case presented, the Illinois court explained, the exclusion might well be held void as against public policy. ${ }^{201}$

Thus, for example, the Supreme Court of Delaware refused to enforce an exclusion clause against both the insured, who drove drunk, and the insured's passenger because the clause was incompatible with the state's adoption of no-fault automobile insurance. ${ }^{202}$ However that conclusion is not universal. Strictly interpreting the insurance contract language as controlling under Minnesota law, the Eighth Circuit allowed an insurer to escape liability to a pedestrian

\footnotetext{
199 Id., separate opinion of Briede \& Salenieks, JJ., II 2.5 (in original, "transportlīdzekḷu īpašnieku civiltiesiskās atbildības obligātā apdrošināšana kḷūst pilnīgi bezjēdzīga").

${ }^{200}$ Bohner v. Ace Am. Ins. Co., 359 Ill. App. 3d 621, 626, 834 N.E.2d 635, 641 (Ill. App. Ct. 2005).

${ }^{201} \mathrm{Id}$.

${ }^{202}$ Bass v. Horizon Assur. Co., 562 A.2d 1194, 1196 (Del. 1989).
} 
injured by the insurer's driver. ${ }^{203}$ The driver, who ran off the road while searching for his ringing cell phone on the car's floor, pleaded guilty to attempted assault, triggering the exclusion even in the absence of criminal intent. ${ }^{204}$

\section{Spain AND THE CASE OF THE DRIVEN GAME}

The Spanish delegate ${ }^{205}$ reported a curious statutory change in motor-vehicle liability law. ${ }^{206}$ By statute, drivers had been responsible in case of collision with animals, ${ }^{207}$ except when the animals were driven by hunting. ${ }^{208}$ However, an amendment in 2014 narrowed the exception. Under the law as amended, drivers bear responsibility even in the hunting scenario-excluding claims for the value of animals themselves - unless the accident resulted directly from collective big game hunting. ${ }^{209}$ Thus, a class of hunting-related animal collisions now leaves drivers without compensation from a defendant hunting party, even when the hunting was a causal factor. ${ }^{210}$ The anticipated impact of the change is a rise in the cost of compulsory first-party insurance for

\footnotetext{
${ }^{203}$ Progressive N. Ins. Co. v. McDonough, 608 F.3d 388, 390-92 (8th Cir. 2010) (Minnesota law).

${ }^{204} I d$.

${ }^{205}$ Albert Ruda, Institute, supra note 1, Apr. 10, 2015 (Spain).

${ }^{206}$ Ley 6/2014, de 7 de abril, por la que se modifica el texto articulado de la Ley sobre Tráfico, Circulación de Vehículos a Motor y Seguridad Vial, aprobado por el Real Decreto Legislativo 339/1990, de 2 de marzo [Law 6/2014, Apr. 7, whereby is modified the article text of the Law on Traffic, Motor Vehicle Traffic, and Road Safety, approved by Royal Legislative Decree 339/1990, Mar. 2] § IX(30) (B.O.E. Apr. 8, 2014, 85, § 1, at 29,508, 29,520 (9th additional provision)) (Spain), http://www.boe.es/diario_boe/txt.php?id=BOE-A-2014-3715.

${ }^{207}$ Cf. generally Rosell Carme, Marc Fernández-Bou, Ferran Camps, Carles Boronat, Ferran Navàs, Mercè Martinez, \& Antoni Sorolla, Animal-Vehicle Collisions: A New Cooperative Strategy Is Needed to Reduce the Conflict, ProceEdings of THE 2013 InTERnATIONAL CONFERENCE ON ECOLOGY AND TRANSPORTATION (ICOET 2013) (monograph), http://www.icoet.net/ICOET_2013/documents/papers/ICOET2013_Paper206B_Rosell_at_al.pdf (abstract and catalog data available from Transportation Research International Documentation Database, http://trid.trb.org/view.aspx?id=1346136) (describing multifaceted problem of animal-vehicle collisions in Europe and specifically study undertaken in Catalonia, Spain, to inform policy recommendations) [http://perma.cc/7F9X344F].

${ }^{208}$ Ruda, Institute, supra note 1.

${ }^{209}$ Law 6/2014 Apr. 7, § IX(30) ("consecuencia directa de una acción de caza colectiva de una especie de caza mayor").

${ }^{210}$ Ruda, Institute, supra note 1.
} 
drivers. $^{211}$ In effect, the insurance system will subsidize hunting activity by relieving hunters of responsibility for an externality of their activity.

A hunting party in the United States may be held liable for a vehicle collision under ordinary negligence principles upon proof of fault. ${ }^{212}$ In a similar vein, a driver in Arizona successfully sued the state for unsafe highway conditions after he collided with an elk. ${ }^{213}$ Evidence submitted to the jury showed state inaction despite a "recorded 168 elk- or deer-related collisions on this eleven-mile stretch of highway within seven years." ${ }^{214}$ Shifting collision liability strictly to drivers is unheard of; even in gun-friendly America, the tendency of statutes is to hold hunters accountable for the externalities of the activity. ${ }^{215}$ Perhaps the Spanish amendment speaks to the power of a special-interest group there. ${ }^{216}$

\section{THE EUROPEAN UNION AND THE CASE OF THE REVERSING TRACTOR}

A concluding presentation on European Union ("EU") law focused on insurance requirements at the European federal level. ${ }^{217}$ EU motor vehicle directives require that motor vehicles be insured for civil liability arising from the "use" of the vehicle. ${ }^{218}$ Slovenian law accordingly provides for compulsory insurance. ${ }^{219}$ European directives require implementation in

\footnotetext{
${ }^{211} \mathrm{Id}$.

212 Booth v. State, 207 Ariz. 61, 65, 83 P.3d 61, 65 (Ct. App. 2004), as amended on reconsideration in part (Mar. $31,2004)$ (contrasting non-liability for conduct of wild animals with negligence-based predicated on defendant's carelessness).

${ }^{213} I d$. at 69.

214 Id. at 68.

215 See, e.g., MONT. CODE ANN. § 45-8-113 (creating liability for "a person in the act of game hunting [who] acts in a negligent manner or knowingly fails to give all reasonable assistance to any person whom the person has injured"); V.I. Code Ann. tit. 12, § 66 2014. ("Whoever hunts upon the lands, waters, or ponds of another with consent, shall, nevertheless, be responsible to the owner for any damage done by himself or his dogs.").

${ }^{216}$ See, e.g., Ibex Hunt Spain, Spanish Big Game, http://www.ibexhuntspain.com/ban/spanish-big-game.php (last visited July 15, 2015) (commercial website boasting that Spain has largest variety in Europe of "big game trophy animals") [http://perma.cc/AM42-YHF2].

217 Thomas Thiede, Institute, supra note 1, Apr. 10, 2015 (European Union).

${ }^{218}$ Council Directive 84/5/EEC, Dec. 30, 1983, O.J. 1984 L 8, p. 17, art. 1(1) (E.U.); Council Directive 72/166/EEC, Apr. 24, 1972, O.J. English spec. ed. 1972 (II), p. 360, art. 3(1) (E.U.).

${ }^{219}$ Zakon o obveznih zavarovanjih v prometu [Law on compulsory insurance in transport] art. 15 (Slovn.).
} 
national law, but member states may request interpretive guidance from the Court of Justice of the European Union (CJEU). ${ }^{220}$ Under this procedure, the Slovenian Supreme Court referred a case in which a man, Vnuk, was working on a farm, on a ladder in front of a barn. ${ }^{221} \mathrm{He}$ fell from the ladder when the ladder was hit by a reversing tractor. ${ }^{22}$ The Slovenian lower courts affirmed the insurer's denial of coverage, holding that compulsory insurance covered only "the use of a tractor as a means of transport, ... not damage caused when a tractor is used as a machine or propulsion device." 223

The CJEU answered in agreement with Vnuk, holding that "use" under the directive, so in the insurance coverage, reaches the tractor as a vehicle in agricultural service as long as the Slovenian courts find that service "consistent with the normal function of that vehicle."224 Offering up a treat for linguaphiles, the court surveyed the implementation of the "use" directives in the languages of various member states. ${ }^{225}$ But ultimately, most persuasive was the "general scheme and purpose of the European Union legislation concerning compulsory insurance,"226 namely, "the dual objective of protecting the victims of accidents caused by motor vehicles and of liberalising the movement of persons and goods" 227 _ ends ill served by a restrictive interpretation.

\footnotetext{
${ }^{220}$ Consolidated Version of the Treaty on the Functioning of the European Union art. 267, 2008 O.J. (C 115/47).

${ }^{221}$ Vnuk v. Zavarovalnica Triglav, Case C-162/13, [2013] E.C.R. I___ (delivered Sept. 4, 2014), II 19 (CJEU), http://curia.europa.eu/juris/document/document.jsf?text=\&docid=157341\&pageIndex=0\&doclang=en \&mode=lst\&d ir $=\&$ occ $=$ first \&part=1\&cid=217459[http://perma.cc/L3LT-J966]

${ }^{222} \mathrm{Id}$.

223 Id. \I 20.

${ }^{224}$ Id. II 59.

${ }^{225}$ Id. III 44-45.

${ }^{226}$ Id. II 47.

${ }^{227}$ Vnuk v. Zavarovalnica Triglav, Case C-162/13, [2013] E.C.R. I___ (delivered Sept. 4, 2014), II 49 (CJEU), http://curia.europa.eu/juris/document/document.jsf?text=\&docid=157341\&pageIndex=0\&doclang=en \&mode=lst \&d ir $=\&$ occ $=$ first $\&$ part $=1 \& \mathrm{cid}=217459$ [http://perma.cc/L3LT-J966]
} 
Almost all of the states in the United States require auto insurance to protect third parties from loss. ${ }^{228}$ But these are road policies. Insurance usually is required only for vehicles used on public roads, and insurance purchased for roadworthy vehicles may be limited on contract terms to exclude recreational or commercial off-road use. Insurers market coverage specially for agribusiness with first-party and third-party options. ${ }^{229}$ In the absence of specially applicable coverage, a farmer would have to rely on a farm owner or umbrella policy, or incur personal liability for fault-based injury.

When insurance coverage is disputed in the United States, courts take their cues from policy language. A farm owner's liability policy was at issue, in an Ohio case, in which a farm tractor had been loaned out to pull trailers in a hayride "bar crawl."230 Plaintiffs were injured when the trailers toppled. ${ }^{231}$ The liability policy contemplated coverage for "recreational vehicles" and excluded coverage for "motorized vehicles." 232 The insurer sought to deny coverage under both parts. ${ }^{233}$ Recreational coverage extended only to vehicles “" designed for recreational use off public roads." 234 Referencing a dictionary definition, the court found the tractor clearly "designed" for farm use, not recreational use, so that part of the policy did not apply. ${ }^{235}$ At the same time, the tractor was a "motorized vehicle," so that part of the policy excluded coverage. ${ }^{236}$ Were the tractor

\footnotetext{
${ }^{228}$ E.g., Shamit Choksey, Car Insurance Requirements by State, http://www.cars.com/go/advice/Story.jsp?section=ins\&subject=ins_req\&story=state-insurance-requirements (June 26, 2013) (last visited July 12, 2015)[http://perma.cc/MGT4-CWTG]

${ }^{229}$ E.g., Farm Bureau Financial Services, Farm Vehicle Insurance Coverage for Trucks, Trailers, Tractors and More, https://www.fbfs.com/insurance/auto-insurance/farm-vehicle-insurance (last visited July 12, 2015)[http://perma.cc/UF3P-6CP5].

${ }^{230}$ United Ohio Ins. Co. v. Schaeffer, 18 N.E.3d 863, 864 (Ohio Ct. App. 2014).

${ }^{231} \mathrm{Id}$.

${ }^{232} I d$. at 866.

${ }^{233} \mathrm{Id}$.

${ }^{234}$ Id. (quoting policy).

${ }^{235}$ United Ohio Ins. Co. v. Schaeffer, 18 N.E.3d 863, 864 (Ohio Ct. App. 2014) (citing WeBSTER's COLLEGIATE DICTIONARY 338 (2003) (“"devise[d] for a specific function or end"”)).

${ }^{236} I d$. at 867.
} 
subject to compulsory registration or "designed for use on public roads," it would not have been an excluded "motorized vehicle."237 So the insurer pointed to the tractor "lights, turn signals, seat belts, a horn, flashing lights, and a slow-moving vehicle sign." ${ }^{238}$ But the court found those features adaptations for only short-term, "field to field" road use, not derogating from the farm-focused design that brought the tractor within the exclusion. ${ }^{239}$

When a policy term is ambiguous, it is construed in favor of the insured. In a Wisconsin case, a man's trailer home and vehicle were both damaged when the defendant's tractor was towing the home and stalled on a hill. ${ }^{240}$ The defendant tractor owner had insured the tractor under his farm owner's policy against third-party losses. ${ }^{241}$ But the insured invoked an exclusion that covered property damage resulting from a mobile home trailer if the trailer was attached to a "motor vehicle," 242 meaning, a vehicle subject to compulsory registration or "“designed for use on public roads." 243 The insured insisted that a tractor when used on a public road comes within the "well-established definition of motor vehicle." 244 But unlike the tractor in Ohio, this Wisconsin tractor, according to the submission of the insured, "was equipped with field tires, and ... was not equipped with brake lights, tail lights, turn signals, or other safety devices for highway use.”245 Unlike the CJEU, the Wisconsin Supreme Court eschewed reference to other instruments in insurance law and confined itself to the meaning of the policy language. ${ }^{246}$ Like the Ohio court, the Wisconsin Supreme Court looked up "design" in the dictionary and determined that the tractor

${ }^{237} I d$. at 866 (quoting policy).

${ }^{238} \mathrm{Id}$.

${ }^{239} \mathrm{Id}$. at 867.

${ }^{240}$ Olson v. Farrar, 809 N.W.2d 1, 5 (Wis. 2012).

${ }^{241} \mathrm{Id}$.

${ }^{242} I d$.

${ }^{243} \mathrm{Id}$.

${ }^{244} I d$. at 11.

245 Id. at 6.

${ }^{246}$ Olson v. Farrar, 809 N.W.2d 1, 12 (Wis. 2012).. 
was designed for farm use, not road use. ${ }^{247}$ But unlike the Ohio court, the Wisconsin court found that definition inconclusive, still subject to broad interpretation, as in any "conceivable purpose" for a tractor, or narrow interpretation, as in, "the particular purpose for which the vehicle is contrived."248 Electing for construction to favor the insured, the court adopted the narrow interpretation.

Both the Ohio and Wisconsin cases involved the same farmowner's policy language, and the courts employed public policy only to achieve proper construction of the terms, not to paint a legal context for a normatively favorable outcome.

\section{OFFICIAL LIABILITY AND CIVIL RIGHTS}

The closely related areas of official liability and private liability in the enforcement of public equal-protection norms constituted a recurring theme in the reported European cases. Problems in government liability arose in the presentations of delegates from Croatia, Czech Republic, Poland, and Romania. The presentation from Hungary contemplated the related but inverse problem of private persons defending against retaliation by public officials. Meanwhile public anti-discrimination norms, as enforceable against private or public defendants, were the subject of the presentations from England and Sweden.

\footnotetext{
${ }^{247}$ Id. (citing AMERICAN HERITAGE DiCTIONARY OF THE ENGLISH LANGUAGE 506 (3d ed. 1992)) (“" to conceive or fashion in the mind; invent' and 'to create or contrive for a particular purpose or effect'"); RANDOM HOUSE UNABRIDGED DICTIONARY 539 (2d ed. 1993) (“"made or done intentionally; intended, planned”")). ${ }^{248} I d$. at $12-13$.
} 


\section{Croatia and the Case of the Unwanted BailifF}

A Croatian case $\mathrm{e}^{249}$ is especially curious, positing a governmental duty of care in lawmaking. ${ }^{250}$ The plaintiff had abandoned his job as a lawyer in anticipation of an appointment as public bailiff in the city of Varaždin. ${ }^{251}$ Before he could start work, the national legislature adopted the Law on the Termination of the Public Bailiffs, which abolished plaintiff's position. ${ }^{252}$ The plaintiff claimed pecuniary and non-pecuniary damages under EU law, as incorporated by the Croatian constitution and the Croatian Law on Obligations. ${ }^{253}$

The legislative defendant argued that there can be no civil wrong in a properly enacted statute, and "that the legislator is free to choose the model of execution it deems to be most effective." 254 The trial court nevertheless found its way to a damages award, and the Croatian Constitutional Court in 2013 ruled the award permissible. ${ }^{255}$ Respecting the opinion of the Constitutional Court, the Croatian County Court, on intermediate appeal, explained that under European human rights norms, the plaintiff, and others similarly situated, suffered a loss of property in the "legitimate expectation" of a public appointment, and that the loss is compensable under the civil code. ${ }^{256}$ The County Court remanded to the Varaždin Municipal Court, which had postponed a hearing on damages pending the disposition on appeal. ${ }^{257}$ Opening the door to a "duty

\footnotetext{
249 Županijski [County Court] Jan. 16, 2014, Varaždin No. G-5818/13-2 (Croat.), available from http://www.iusinfo.hr/LegisRegistry/Content.aspx?SOPI=ZSRH2013581B8A2\&Doc=ZUPSUD_HR[ http://perma.cc/5BDU-FU3W]. (pay wall) (translated to English by Google Translate) I am grateful to Professor Marko Baretić for sharing with me a copy of this decision, which I have on file.

${ }^{250}$ Marko Baretić, Institute, supra note 1, Apr. 10, 2015 (Croatia).

${ }^{251}$ Varaždin No. G-5818/13-2.

${ }^{252} I d$.

${ }^{253}$ Id. (citing Sabor [Constitution] art. 145 (Croat.) (articulating principle of acquis communautaire)); Law on Obligations art. 1046 (Croat.).

${ }^{254}$ Id. (in original, "da je zakonodavac slobodan odabrati model ovrhe za koji smatra da će najdjelotvornije").

${ }^{255}$ Id. (citing Ustavni [Constitutional Court] Jan. 23, 2013, Nos. U-I-5612/2011, U-I-6274/2011, U-I-178/2012, U-I-480/2012 (Croat.), available from http://narodne-novine.nn.hr/clanci/sluzbeni/2013_01_13_201.html)[ http://perma.cc/MU2X-QKPE].

${ }^{256} I d$. (in original, "legitimno očekivanje").

${ }^{257} I d$.
} 
of care" in law-making, the case raises big questions, from what constitutes a wrongful act to how damages are to be measured. ${ }^{258}$

The withholding of the public appointment in Varaždin has a nostalgic Marbury v. Madison ring to it. ${ }^{259}$ But Marbury pitted President against Congress, not private plaintiffs against Government. ${ }^{260}$ The U.S. Supreme Court has rejected theories of affirmative duty on the part of executive officials arising in constitutional law. ${ }^{261}$ The notion of legislative negligence vis-à-vis the populace would have vast implications for public policy. Springing to mind is the recent climate change decision in the Netherlands, in which the Hague District Court ordered the Dutch government to cut carbon emissions. ${ }^{262}$ The Hague lawsuit was authorized by the Dutch Constitution; ${ }^{263}$ statutory waivers of U.S. sovereign immunity are not nearly as generous. ${ }^{264}$

In U.S. common law, the public trust doctrine posits that some natural resources are held in trust by the government for the public, so that they may not be misused or alienated. ${ }^{265} \mathrm{~A}$ "potent common law doctrine" derived from Roman civil law and English common law, ${ }^{266}$ public trust has played a meaningful modern role in preserving water resources in the West. ${ }^{267}$ The U.S. Supreme Court in 1892 recognized the doctrine in defining Chicago's authority over navigable water in the Great Lakes, ${ }^{268}$ though the Court in 2012 had occasion to opine that the public trust

\footnotetext{
258 Baretić, Institute, supra note 1.

${ }^{259}$ Marbury v. Madison, 5 U.S. 137, 138-139 (1803).

${ }^{260} \mathrm{Id}$. at 137.

${ }^{261}$ DeShaney v. Winnebago Cnty. Dep’t of Soc. Servs., 489 U.S. 189, 202, 109 S. Ct. 998, 1007, 103 L. Ed. 2d 249 (1989).

262 Hague District Court June 24, 2015, No. C/09/456689 / HA ZA 13-1396 (Neth.), http://uitspraken.rechtspraak.nl/inziendocument?id=ECLI:NL:RBDHA:2015:7196 [http://perma.cc/YPW2-MAMS ](English translation).

${ }^{263}$ Id. II 4.36 (citing Const. art. 21 (Neth.)).

${ }^{264}$ See 28 U.S.C. $\$ \S 1346($ b)(1), 2680.

2651 ENVTL. L. (West) § 2:20 (WestlawNext database updated June 2015).

${ }^{266}$ Hope M. Babcock, The Public Trust Doctrine: What A Tall Tale They Tell, 61 S.C. L. REV. 393, 396-97 (2009).

267 E.g., Nat'l Audubon Soc'y v. Superior Court, 33 Cal. 3d 419, 451, 658 P.2d 709, 731-32 (1983) (affirming jurisdiction based on public trust doctrine for judicial review of challenged diversions from natural lake).

${ }^{268}$ Ill. Cent. R.R. Co. v. State of Illinois, 146 U.S. 387, 458-59, 13 S. Ct. 110, 120, 36 L. Ed. 1018 (1892).
} 
doctrine is a creature of state, not federal, law. ${ }^{269}$ Much speculation surrounds potential application of the public trust doctrine in the Dutch vein, ${ }^{270}$ but efforts so far have made little headway. Key cases at state and federal levels were dismissed in 2014 for want of subject-matter jurisdiction. ${ }^{271}$

Commenters have observed that the public trust doctrine often gets a chilly reception in U.S. courts because it seems to run counter to private property rights and democratic policymaking. ${ }^{272}$ The latter concern is implicated well by a climate-change suit in Oregon, predicated on the public trust doctrine and ongoing at the time of this writing. ${ }^{273}$ The trial court has twice rejected the suit, now on appeal for the second time, and the court's reasoning maps four substantial hurdles that are bound to undermine a legislative-duty claim in U.S. law, whether at the state or federal level.

First, the trial court held that the plaintiffs' action was not authorized by the state declaratory judgment statute. ${ }^{274}$ The plaintiffs wanted more than just a declaration of state noncompliance with a statute or constitutional provision, the court explained, because there was no pre-existing law requiring the state to regulate greenhouse gas emissions in the manner plaintiffs

\footnotetext{
${ }^{269}$ PPL Mont., LLC v. Montana, 132 S. Ct. 1215, 1235, 182 L. Ed. 2 d 77 (2012); but see Amicus Curiae Brief of Law Professors in Support of Granting Writ of Certiorari, Alec L. v. McCarthy, No. 14-405, 2014 WL 5841697, at 3-8 (U.S. filed Nov. 8, 2015) (arguing that public trust doctrine has role in limiting federal power that simply was not implicated in PPL Montana).

${ }^{270}$ E.g., Robin Kundis Craig, Adapting to Climate Change: The Potential Role of State Common-Law Public Trust Doctrines, 34 VT. L. REV. 781, 798-805 (2010); Julia B. Wyman, In States We Trust: The Importance of the Preservation of the Public Trust Doctrine in the Wake of Climate Change, 35 VT. L. REV. 507, 508-09 (2010).

${ }^{271}$ Alec L. v. McCarthy, 561 Fed. Appx. 7, 8 (D.C. Cir.) (mem. per curiam), cert. denied, 135 S. Ct. 774 (2014); Texas Comm'n on Envtl. Quality v. Bonser-Lain, 438 S.W.3d 887, 895 (Tex. Ct. App. 2014).

272 Babcock, supra note 266, at 393 \& n.1.

${ }^{273}$ Chernaik v. Brown (Chernaik III), No. 16-11-09273 (Or. Cir. Ct. Lane Cty. May 11, 2015), available from http://courts.oregon.gov/Lane/docs/Chernaik\%20v\%20Brown\%200pinion.pdf, after remand from (Chernaik II) 263 Or. App. 463, 481, 328 P.3d 799, 808 (Or. Ct. App. 2014), which rev'd (Chernaik I) 2012 WL 10205018 (Or. Cir. Ct. Lane Cnty. Apr. 5, 2012).

${ }^{274}$ Chernaik I, 2012 WL 10205018, *4 (Or. Cit. Ct. Lane Cty. May 11, 2015) (construing OR. Rev. STAT. §§ 28.010 to 28.160$)$.
} 
demanded. ${ }^{275}$ Rather, the plaintiffs sought "to impose a new affirmative duty" on the state, and the declaratory judgment act gave the court no such authority. ${ }^{276}$

Second, the trial court held that the plaintiffs' action was barred by sovereign immunity under the Oregon Constitution. ${ }^{277}$ Again, plaintiffs' claims did not assert that public officials had exceeded their delegated authority under any pre-existing law. ${ }^{278}$ No statutory waiver of sovereign immunity in Oregon subjects state officials to potential liability for exercising discretion within the scope of their authority. ${ }^{279}$

Third, the trial court held that the plaintiffs' action was barred by the separation of powers doctrine under the Oregon Constitution. ${ }^{280}$ Plaintiffs would have had the court direct the legislature to regulate greenhouse gas emissions. ${ }^{281}$ In essence, the plaintiffs would have had the court "substitute its judgment for that of the Legislature," creating an undue burden on a coordinate branch of government and usurping the legislation function "to decide politically_based upon whatever facts it deems relevant to the determination — whether or not global warming is a problem and what, if anything, ought to be done about it."282

Fourth, the trial court held that the plaintiffs' action was barred by the political question doctrine. ${ }^{283}$ The court reasoned that the plaintiffs' sought-after relief first required the court to make "an initial policy determination" on greenhouse gas emissions, a role for which the judiciary

275 Id. at $* 3-* 4$.

${ }^{276} I d$.

${ }^{277} I d$. at $* 4-* 5$ (construing OR. CONST. art. IV, § 24).

278 Id. at $* 5$ \& n. 6 .

${ }^{279} I d$. at *5. Cf. 28 U.S.C. $§ 2680$ (a) (excepting from sovereign immunity waiver federal official's "discretionary function or duty").

${ }^{280}$ Chernaik I, 2012 WL 10205018, at*7 (Or. Cir. Ct. Lane Cty. Apr. 5, 2012) (construing OR. ConsT. art. III, § 1).

281 Id. at $* 6$.

282 Id. at $* 6-* 7$.

${ }^{283} I d$. at $* 8$. 
is ill suited. ${ }^{284}$ The plaintiffs' relief would then compel the court to quantify emission targets, a prohibitive chore that unveils in the public trust doctrine an impermissible dearth "of judicially discoverable and manageable standards."285

The appellate court remanded the Oregon case, opining that the trial court had improperly focused on plaintiffs' demand for relief with respect to emission regulation, to the detriment of plaintiffs' more modest demands, such as simple declaration that the public trust doctrine does impose a duty on the state to ensure air purity in some measure. ${ }^{286}$ On remand, the trial court answered the simple public trust question in the negative, holding that the doctrine applies to water and not to air. ${ }^{287}$ Moreover, the court reiterated its position on the separation of powers and political question doctrines. ${ }^{288}$ The case is on subsequent appeal, but its prognosis is poor.

\section{CZECh RePublic And the CASE OF THE Not-So-STOlEn CoINS}

Reminiscent of the Snowden revelations, which boosted the clarion call for privacy protection in the EU, a Czech case ${ }^{289}$ involved wiretapping by public officials. ${ }^{290}$ Investigating $^{2}$ the sale of a coin collection suspected of being stolen, police wiretapped plaintiff's telephone and searched his home. ${ }^{291}$ No evidence of wrongdoing was discovered, and the plaintiff demanded an apology and about $€ 3600$ in non-pecuniary damages. ${ }^{292}$ Statute provided the plaintiff no cause of action predicated on improper judicial approval of the police investigation. ${ }^{293}$ But the court

\footnotetext{
${ }^{284} \mathrm{Id}$.

${ }^{285} \mathrm{Id}$.

286 (Chernaik II) 263 Or. App. 463, 475, 328 P.3d 799, 805 (Or. Ct. App. 2014),

${ }^{287}$ Chernaik v. Brown (Chernaik III), No. 16-11-09273 at 13 (Or. Cir. Ct. Lane Cty. May 11, 2015).

${ }^{288}$ Id. at $14-18$.

289 Nejvyšší Soud [Supreme Court] Dec. 4, 2014, No. 30 Cdo 4286/2013 (Czech Rep.), http://kraken.slv.cz/30Cdo4286/2013 (translated to English by Google Translate).

${ }^{290}$ Jiří Hrádek, Institute, supra note 1, Apr. 10, 2015 (Czech Republic).

291 No. 30 Cdo 4286/2013.

292 Id.

${ }^{293}$ Id.
} 
concluded that a constitutional complaint, predicated on court precedents, must be permitted by the tandem operation of privacy protection under the European Convention on Human Rights and the Czech judicial power under the Czech constitution. ${ }^{294}$ A constitutional complaint allows the plaintiff to demand cancellation of the judicial search order, and that cancellation in turn allows the plaintiff to seek damages under the state liability law. ${ }^{295}$

The hang-up in the Czech courts was largely procedural, and human rights norms afforded the court a workaround. In the United States, both the civil rights law $^{296}$ and the Constitution itself $^{297}$ afford causes of action against public officials for violation of the right against unreasonable search and seizure. Because civil rights violations are treated like torts, the plaintiff who can overcome qualified immunity and meet the burden of proof may claim compensatory damages. ${ }^{298}$ Damages may not be awarded to represent abstract rights violation, but may, as in a tort action, include actual non-pecuniary loss, such as reputational harm and mental anguish, in addition to pecuniary loss. ${ }^{299}$ This approach is consistent with the Czech case, in which the plaintiff's cause of action was facilitated by human rights norms, but his damages award was dictated by the civil code.

\footnotetext{
${ }^{294}$ Id. (citing European Convention for the Protection of Human Rights and Fundamental Freedoms arts. 8 (privacy), 13 (remedy); Ústava [Constitution] art. 83 (Czech Republic), available from http://www.psp.cz/docs/laws/constitution.html).

${ }^{295}$ Id. (citing Reg. No. 82/1998Sb., § 8, II 1 (Czech Rep.)).

29642 U.S.C. $\S 1983$.

${ }^{297}$ Bivens v. Six Unknown Named Agents, 403 U.S. 388 (1971) (construing U.S. CONST. amend. IV).

2982 STATE AND LOCAL GOVERNMENT CiVIL RightS LiABILITY $§ 2: 24$ (WestlawNext database updated June 2015 ); 1 Stein On PERSONAL InJURy DAMAGES TREATISE $§$ 5:18 (3d ed.) (WestlawNext database updated Apr. 2015).

${ }^{299}$ Memphis Cmty. Sch. Dist. v. Stachura, 477 U.S. 299, 307, 106 S. Ct. 2537, 2543, 91 L. Ed. 2 d 249 (1986).
} 


\section{POlAND AND THE CASE OF THE AILING SOLDIER}

A Polish case ${ }^{300}$ addressed no-fault state liability in a military context with compelling facts. $^{301}$ A soldier contracted life-threatening meningitis. He was comatose for three weeks and suffered nephrectomy, skin grafts, and the amputation of fingers and both feet. ${ }^{302}$ At age 25 , plaintiff is permanently unable to work or live independently, bears scarring over more than half his skin surface, and will face indefinitely ongoing treatment and risk of complications. ${ }^{303}$ The plaintiff claimed damages under the civil code from the military, pointing to epidemiological studies tracing infection likely to other soldiers, and claiming failure to vaccinate properly and negligent diagnosis and treatment. ${ }^{304}$ The lower court found plaintiff's claim ill founded under the civil code provisions governing fault-based liability and claims against the state for unlawful acts. $^{305}$ But the court awarded about $€ 118,000$ under the provision for claims against the state for lawful acts. ${ }^{306}$ The intermediate appellate court upheld the award but corrected the basis to the provision for claims against the state for unlawful acts, and moreover doubled the liability award, in light of plaintiff's extraordinary suffering. ${ }^{307}$ The Polish Supreme Court restored the earlier judgment, on the basis of lawful acts, holding that the plaintiff had failed to establish the requisite civil probability of causation connecting official misfeasance and the plaintiff's illness. ${ }^{308}$ The delegate from Poland explained that the decision is significant both for having observed the civil

\footnotetext{
300 Sąd Najwyższy [Supreme Court] Mar. 7, 2013, No. II $\quad$ CSK $364 / 12 \quad$ (Pol.), http://www.sn.pl/Sites/orzecznictwo/Orzeczenia2/II\%20CSK\%20364-12-1.pdf (translated to English by Google Translate).

${ }^{301}$ Ewa Bagińska, Institute, supra note 1, Apr. 10, 2015 (Poland).

302 Sąd Najwyższy, supra note 300.

${ }^{303} \mathrm{Id}$.

${ }^{304}$ Id.

${ }^{305} I d$. (citing, respectively, Civ. Code arts. 415, 417, § 1 (Pol.)).

${ }^{306}$ Id. (citing Civ. Code art. 417, $\S 2$ (Pol.)).

${ }^{307} \mathrm{Id}$.

${ }^{308} I d$.
} 
probability standard in probing the lawfulness of official conduct, and for compensating in the interest of justice anyway, on a strict-liability basis, at least in case of "particularly severe personal injury." 309

Medical malpractice by public officials in the United States can be an authorized claim under the Federal Tort Claims Act. ${ }^{310}$ However, the Feres doctrine, derived from a 1950 U.S. Supreme Court case, bars claims by service members on active duty whose injuries are incident to military service. ${ }^{311}$ Incidence to military service marks a fine line, ${ }^{312}$ which is policed by three rationales for the Feres doctrine: (1) the "distinctive . . . federal character" of the relationship between Government and soldier; (2) the availability of no-fault veteran benefits for injured soldiers; and (3) the effect on military discipline of allowing a soldier to claim negligence by a superior. ${ }^{313}$ Active duty is key, so even a soldier who injured his knee playing basketball "off duty," while on active duty, was barred from a claim arising from his treatment. ${ }^{314}$ In more tragic circumstances, the Feres doctrine barred the estate claim when improper administration of an epidural resulted in the death from meningitis of an expectant mother on active duty. ${ }^{315}$ The Polish facts playing out in the United States therefore would come within the Feres doctrine. Close

\footnotetext{
${ }^{309}$ Bagińska, Institute, supra note 1.

31028 U.S.C. $\S \S 1346(\mathrm{~b})(1)$; see also 28 U.S.C. $\$ 2680(\mathrm{j})$ (disallowing "[a]ny claim arising out of the combatant activities of the military or naval forces, or the Coast Guard, during time of war").

${ }^{311}$ Feres v. United States, 340 U.S. 135, 146, 71 S. Ct. 153, 159, 95 L. Ed. 152 (1950).

${ }^{312}$ For example, a mother who alleged negligent treatment during pregnancy while she was on active duty, resulting in the child's death as a newborn, saw her claim barred by the Feres doctrine. Irvin v. United States, 845 F.2d 126, 131 (6th Cir. 1988). But, another mother who alleged negligent treatment during pregnancy while she was on active duty, also resulting in the child's death as a newborn, was allowed her claim on the thinly distinguishing ground that the alleged negligence effected no physical injury to the mother, but only to the civilian child. Brown v. United States, 462 F.3d 609, 614 (6th Cir. 2006).

${ }^{313}$ Stencel Aero Eng'g Corp. v. United States, 431 U.S. 666, 671-72, 97 S. Ct. 2054, 2058, 52 L. Ed. 2d 665, 671-72 (1977) (internal quotation marks omitted).

314 Borden v. Veterans Admin., 41 F.3d 763, 763 (1st Cir. 1994) ("straightforward application of the 'incident to service' test ... depends on plaintiff's military status in relation to defendant's allegedly negligent provision of medical treatment").

${ }^{315}$ Hancox v. Performance Anesthesia, P.A., 455 F. Appx. 369, 370-71, 373 (4th Cir. 2011) (per curiam).
} 
quarters and vaccination prescriptions were blamed as causal factors of the Polish plaintiff's suffering, and those factors much more directly implicate military policy and discretion than a soldier's routine healthcare that happens to coincide with time on active duty. ${ }^{316}$

\section{ROMANiA AND THE CASE OF THE HOBBLED AIRPORT}

The stakes were less dramatic, but the principle similar, in a Romanian case ${ }^{317}$ arising from the construction of a public highway. ${ }^{318}$ The case represented an exemplary application of a newly adopted civil liability code. ${ }^{319}$ A small airport clashed with the government when construction of a city ring road impaired airport operation. ${ }^{320}$ The court ran down the essential requirements of tort under the new civil code, and found them present on the facts: the plaintiff's loss in the financial cost of relocating navigation equipment, ${ }^{321}$ and a direct causal link between the plaintiff's loss and the defendant's construction. ${ }^{322}$ The government, in its defense, tried to move the case into the law of takings, which would implicate far less cost than tort liability for the airport's pecuniary losses. ${ }^{323}$ Under the old civil code, a lawful taking for the public good vitiated legal causation in tort, and the trial court had accepted the government's argument that the same theory should apply under the new civil code. ${ }^{324}$ The high court reversed and held the government liable, pointing to plain and unqualified language of duty and responsibility in the new civil code. ${ }^{325}$

\footnotetext{
316 Sąd Najwyższy [Supreme Court] Mar. 7, 2013, No. II CSK 364/12 (Pol.), http://www.sn.pl/Sites/orzecznictwo/Orzeczenia2/II\%20CSK\%20364-12-1.pdf (translated to English by Google Translate).

317 Înalta Curte de Casație și Justiție [High Court of Cassation and Justice] June 24, 2014, Sec. II Civ. No. 2358 (Rom.), http://www.juridice.ro/wp-content/uploads/2014/10/Dec-iunie-2014.htm [http://perma.cc/EQF8-27X4] (translated to English by Google Translate).

${ }^{318}$ Christian Alunaru, Institute, supra note 1, Apr. 10, 2015 (Romania).

${ }^{319}$ Id.; see No. 2358, II 57 (comparing former Civ. Code art. 998 (Rom.) with new Civ. Code $§ 1349$ (Rom.)).

${ }^{320}$ No. 2358, গII 21, 24, 26, 30.

${ }^{321}$ Id. II 30.

322 Id. II 31.

${ }^{323}$ Id. II 35.

${ }^{324}$ Id. TII 37, 43, 48.

${ }^{325}$ Id. II 57.
} 
Cases in the United States with similar facts also walk the line between takings and tort. Complaining of negligence, and taking in the alternative, a Texas couple complained that state highway construction caused their land to flood. ${ }^{326}$ The court affirmed an award in negligence based on a private claim statute, but observed that the taking claim otherwise would have held water. ${ }^{327}$ Framing the two theories as working in tandem, a South Carolina plaintiff alleged that negligent highway relocation effected a taking of his farmland by flooding, though the case failed for insufficient proof of causation. ${ }^{328}$ When highway construction in Kansas caused plaintiffs' yards to subside, they were able to pursue a takings theory even when their negligence claims were blocked by sovereign immunity. ${ }^{329}$ But, the plaintiff in another Texas case was not as lucky. When the state's roadside grass burning spread to the plaintiff's field and destroyed his hay crop, the plaintiff's negligence claim was blocked by sovereign immunity. ${ }^{330}$ The court moreover refused the plaintiff's takings theory, reasoning that takings must be accomplished for the public good, while the fire was purely an accident sounding only in tort. ${ }^{331}$ These cases generally accord with the new Romanian approach allowing tort recovery, provided that plaintiff is able to make the proof of negligence and that code vitiates sovereign immunity. ${ }^{332}$

\footnotetext{
${ }^{326}$ State v. Hale, 146 S.W.2d 731, 731-34 (Tex. 1941).

${ }^{327}$ Id. at 34-35, 43.

328 Owens v. S. Carolina State Highway Dep't, 121 S.E.2d 240, 241-42, 247 (S.C. 1961).

${ }^{329}$ Sanders v. State Highway Comm 'n, 508 P.2d 981, 984-85, 987-88 (Kan. 1973).

${ }^{330}$ Texas Highway Dep 't v. Weber, 219 S.W.2d 70, 70-71 (Tex. 1949).

${ }^{331}$ Id. at 71-72.

332 No. 2358, II 57.
} 


\section{Hungary and the Case of the Pictured Police}

Public-private tables were turned in a Hungarian case ${ }^{333}$ that started with a civil suit by police against journalists. ${ }^{334}$ Hungarian privacy law prohibited publication of identifiable images of persons without their consent, ${ }^{335}$ a principle the Constitutional Court traced from the American "right to be let alone" through European concepts of autonomy and personal integrity. ${ }^{336}$ The law extended to police, even in the performance of their duties, resulting in edited journalistic images in Hungarian media - sometimes with superimposed cutouts of images such as animal heads, meaning to mock the law. ${ }^{337}$ The petitioner, an online news service, published images in violation of the law, in which two officers were recognizable while participating in a demonstration of the law enforcement union. ${ }^{338}$ Offended police succeeded in a suit against the newspaper in municipal court. $^{339}$ The petitioner brought a constitutional complaint, asking the Constitutional Court to nullify the lower court's ruling on grounds of freedom of expression. ${ }^{340}$ The Constitutional Court decided that it bore an obligation to balance the human rights of expression and privacy. ${ }^{341}$ Expressive freedom serves functions of public accountability and democratic opinion-forming. ${ }^{342}$ Privacy law protects "confidentiality, anonymity, and solitude." ${ }^{343}$ On balance, the court found persuasive that the police were pictured in a public place, at an event of public interest, and the portrayal was not "insulting, degrading, hurtful, or distorted . . or a bad impression of the depicted

333 Alkotmánybíró [Constitutional Court] Sept. 23, 2014, No. 28/2014 (IX.29) (Hung.), http://public.mkab.hu/dev/dontesek.nsf/0/0E56D3CAD2A42323C1257B91001BAA15?OpenDocument [http://perma.cc/2R2J-YH7F] (translated to English by Google Translate).

334 Attila Menyhárd, Institute, supra note 1, Apr. 10, 2015 (Hungary).

${ }^{335}$ No. 28/2014 (IX.29), TII 24, 28, 32 (citing Civ. Code $\S \S 2: 423,2: 43,2: 48,80$ (Hung.)).

${ }^{336}$ Id. IIIT 22, 25 (citing European Convention for the Protection of Human Rights and Fundamental Freedoms art. 8).

${ }^{337}$ Menyhárd, Institute, supra note 1.

${ }_{338}^{338}$ No. 28/2014 (IX.29), II 40.

${ }^{339}$ Id. II 4.

${ }^{340}$ Id. II 1.

${ }^{341}$ Id. IIII $18,35$.

${ }^{342}$ Id. TIII 16-17.

${ }^{343}$ Id. II 22 (in original, “titkosság, az anonimitás, és a magányhoz”). 
persons." 344 The civil code on its own terms provides that it yields to constitutional imperatives, and the Constitutional Court accordingly nullified the rulings below. ${ }^{345}$

Restrictions on photographing police in public places, or for that matter restrictions on photographing anyone in a public place, would have seemed utterly contrary to the spirit of free expression when the First Amendment emerged from Civil Rights-era transformation 45 years ago. But now, in the age of pervasive media and virtual identity threats, the wall that once neatly divided public and private spheres is giving way ${ }^{346}$ to thermal imaging ${ }^{347}$ and satellite tracking. ${ }^{348}$ The First Amendment never was construed as a right to gather information. ${ }^{349}$ But with data protection having emerged in Europe as a new human right, ${ }^{350}$ privacy is assuming a new legal character that increasingly resonates with constitutional amplitude. ${ }^{351}$ At the same time, police are lately beset with charges of misconduct, ${ }^{352}$ precipitating a public desire to know what police are up to. Exhibiting its cliché duality, ${ }^{353}$ technology such as police body cameras compromises privacy while promising accountability. ${ }^{354}$ Thus far in the United States, lower courts confronted with the

\footnotetext{
${ }^{344} I d$. III 41, 48 (in original, "bántó, lealacsonyító vagy torz képet közvetítenek, vagy rossz benyomást keltenek az ábrázolt személyekröl").

${ }^{345}$ Id. III 44, 49 (citing Civ. Code art. 1:2 (Hung.)).

${ }^{346}$ E.g., Robert Ellis Smith, Sometimes, What is Public is Private, 59 R.I. BAR J. 33 (2011).

${ }^{347}$ See Kyllo v. United States, 533 U.S. 27, 29-31 (2001).

${ }^{348}$ See United States v. Jones, 132 S. Ct. 945,947 (2012).

${ }^{349}$ Cohen v. Cowles Media Co., 501 U.S. 663, 670, 111 S. Ct. 2513, 2518, 115 L. Ed. 2d 586 (1991) (maintaining that newsgathering must give way to generally applicable laws); see also Shulman v. Grp. W Prods., Inc., 18 Cal. 4th 200, 238, 955 P.2d 469, 495, as modified on denial of reh'g (July 29, 1998) ("the press in its newsgathering activities enjoys no immunity or exemption from generally applicable laws").

${ }^{350}$ Charter of Fundamental Rights of the European Union, 2010/C 83/02, art. 8.

${ }^{351}$ See, e.g., Nat'l Aeronautics \& Space Admin. v. Nelson, 562 U.S. 134, 143-47 (2011) (discussing informational privacy right, applied by court of appeals but only assumed arguendo in U.S. Supreme Court).

${ }^{352}$ E.g., Michael Hirsh, Tackling America's Police Abuse Epidemic, Politico (Apr. 9, 2015), http://www.politico.com/magazine/story/2015/04/north-charleston-shooting-americas-police-abuse-epidemic116838.html\#.VaMx6PmnfPI [http://perma.cc/QD43-EBPY].

353 See, e.g., L. Gordon Crovitz, Is Technology Good or Bad? Yes., Wall. St. J., (Aug. 23, 2010), http://www.wsj.com/articles/SB10001424052748703579804575441461191438330.

${ }^{354}$ Chapter Four Considering Police Body Cameras, 128 HARV. L. ReV. 1794, 1800-14 (2015) (analyzing pro-con arguments); see also Howard M. Wasserman, Commentary: Moral Panics and Body Cameras, 92 WASH. U. L. REV. 831 (2014) (analyzing argument rhetoric).
} 
audio- and video-recording of police performing official duties have held the activities protected by the First Amendment. ${ }^{355}$ Nevertheless, contested cases persist and in time will probe the limits of the right to record. ${ }^{356}$

\section{England AND THE CASE OF THE CAPTIVE Au PAIR}

An English case ${ }^{357}$ facilitates the enforcement of public anti-discrimination norms against private parties. ${ }^{358}$ Plaintiff Hounga, a 14-year-old Nigerian national, was invited to work as an au pair ${ }^{359}$ for the Allen family in the United Kingdom. ${ }^{360}$ Hounga knowingly participated in a plan with the Allens to misrepresent her age and identity, to obtain and overstay a six-month visitor's visa, and to work illegally. ${ }^{361}$ But contrary to their agreement, Hounga was not compensated with the agreed-upon $£ 50$ per month and access to education. ${ }^{362}$ To the contrary, she suffered threats and serious physical abuse, and after 18 months was terminated and evicted. ${ }^{363}$ Hounga brought actions against Mrs. Allen in tort and contract, and also for violation of the Race Relations Act 1976, claiming discrimination on the impermissible ground of nationality. ${ }^{364}$ The lower courts dismissed Hounga's contract and tort claims upon the defense of illegality. ${ }^{365}$

\footnotetext{
${ }^{355}$ E.g., Glik v. Cunniffe, 655 F.3d 78, 83 (1st Cir. 2011) ("the First Amendment protects the filming of government officials in public spaces"); see Sophia Cope, Police Must Respect the Right of Citizens to Record Them, ELEC. FRONTIER FOUND., Apr. 16, 2015, https://www.eff.org/deeplinks/2015/04/police-must-respect-right-citizens-recordthem [http://perma.cc/R78R-N8N9].

356 See Robinson Meyer, What to Say When the Police Tell You to Stop Filming Them, AtLanTiC, Apr. 28, 2015, http://www.theatlantic.com/technology/archive/2015/04/what-to-say-when-the-police-tell-you-to-stop-filmingthem/391610/ [http://perma.cc/CL4G-PPPW].

${ }^{357}$ Allen v. Hounga, [2014] U.K.S.C. 47, 1 W.L.R. 2889.

${ }^{358}$ Annette Morris, Institute, supra note 1, Apr. 10, 2015 (England \& Wales).

${ }^{359}$ An "au pair" is a young person, usually a woman, from a foreign country who lives with a family and helps with childcare and housework in return for the opportunity to learn the family's language. Au Pair, MERRIAMWEBSTER.COM, http://www.merriam-webster.com/dictionary/au\%20pair (last visited Feb. 23, 2016).

${ }^{360}$ Allen, 1 W.L.R. 2889, II 2.

${ }^{361}$ Id. .ाTा6-11.

${ }^{362} I d$. II 13.

${ }^{363}$ Id. IIII $14-15$.

${ }^{364}$ Id. II 16.

${ }^{365}$ Allen, 1 W.L.R. 2889, II 24.
} 
However, the U.K. Supreme Court balked on the application of the defense to the discrimination claim. ${ }^{366}$ Ordinarily the defense of illegality preserves the integrity of the legal system by precluding an actor's windfall from unlawful activity. ${ }^{367}$ However, "if the defendant's behaviour was truly disproportionate overall, it might be powerful evidence that the claimant's criminal conduct was not sufficiently linked to the injuries so as to attract the defence." ${ }^{268}$ To reject Hounga's claim on the basis of her efforts to obtain employment and education, even if through illegal means, would put the court in the position of "appear[ing] to condone the illegality" of human trafficking, which international and U.K. human rights law recognizes as the far greater evil. $^{369}$

Despite the shared common law heritage of the United Kingdom and United States, the British court's trouble with the defense of illegality likely would not be a problem upon similar facts in America. Professor Robert Prentice explicated the history of the illegality defense, otherwise known as the defense of unlawful conduct or the doctrine ex turpi causa non oritur actio,${ }^{370}$ beginning with its arguably unwise importation from contract to tort. ${ }^{371}$ Analyzing the contemporary plight of the historic defense in tort, Prentice found it thriving in Australia, resurging in England, and "virtually disappeared" in the United States. ${ }^{372}$ The Second Restatement of Torts trumpeted the defense's demise, declaring simply: "One is not barred from recovery for an

\footnotetext{
366 Id. II 25.

${ }^{367}$ Id. .ाI 43-44.

${ }^{368}$ Id. II 32.

${ }^{369}$ Id. पIT 35, 45-52 (internal quotation marks omitted).

${ }^{370}$ My translation: no action arises from a turpid condition.

${ }^{371}$ Robert A. Prentice, Of Tort Reform and Millionaire Muggers: Should an Obscure Equitable Doctrine Be Revived to Dent the Litigation Crisis?, 32 SAN DIEGO L. REV. 53, 57-66 (1995).

${ }^{372}$ Id. at 66-88.
} 
interference with his legally protected interests merely because at the time of the interference he was committing a tort or a crime ..."373

Already four decades before the Second Restatement, Massachusetts qualified the illegality defense to apply only when the illegality was a "directly contributing cause" to the injury. ${ }^{374}$ Thus, the court obviated the absurd outcome that a plaintiff illegally in the United States would be unable to recover when hit by a car. ${ }^{375}$ The court explained that the plaintiff's illegal entry "into the country $\mathrm{d}[\mathrm{id}]$ not so taint his ... peaceful presence as to preclude . . . redress." ${ }^{376}$ As with all analyses of extended causation, the question is one of degree. The Restatement illustrated intentional harms between conspirators: "if two robbers dispute over the spoils and one of them shoots the other, the other has a cause of action for the physical harm, although he would not have a cause of action because of a refusal by the other to divide the spoils." ${ }^{377}$ The successful robbery was a cause of both the ill division of spoils and the shooting, but a direct, or substantial, cause only of the former.

Similarly, Hounga would not be able to sue Allen in U.S. law (in contract or tort) for the $£ 50$ monthly stipend or denial of educational opportunity. Those are spoils ill divided, losses resulting directly from an illegal bargain. But Hounga should be able to sue for physical abuse and civil rights violations, which are beyond the scope of the illegal bargain: closer to the alien hit by the car, about at shooting between conspirators, and well beyond ill divided spoils. The outcome then is the same as the English court's, but "[t]he legal concept of cause comes to the rescue in

\footnotetext{
373 RESTATEMENT (SECOND) OF TORTS $\$ 889$ (1979).

374 Janusis v. Long, 284 Mass. 403, 410, 188 N.E. 228, 231 (1933).

375 Id. at 231-32.

${ }^{376} \mathrm{Id}$.

${ }^{377}$ RESTATEMENT (SECOND) OF TORTS $§ 889 \mathrm{cmt}$. c. (internal citation omitted).
} 
these cases" ${ }^{378}$ in America, doing the dirty work of an otherwise hazardously idiosyncratic test for disproportionality.

\section{SWEDEN AND THE CASES OF THE FOUL-MOUTHED DRIVER AND THE FUSSY FERTILITY}

CLINIC

Two cases from Sweden, decided the same day in the Swedish Supreme Court, ${ }^{379}$ concerned discrimination. ${ }^{380}$ In both cases, the methodology and quantum of damages were the issues on appeal; however, the delegate from Sweden brought the cases to the floor to comment on their significance on the merits in anti-discrimination law. ${ }^{381}$ Claimants won awards in both cases, signaling expansive judicial interpretation of anti-discrimination offenses. ${ }^{382}$ Moreover, the underlying facts are provocative in light of the stress lines appearing recently on the famously welcoming face of Swedish immigration policy. ${ }^{383}$

In the first case, the driver of a crowded Veolia Transport bus was perturbed when a patron, "FJ," repeatedly inadvertently struck a stop-request button with her knee. ${ }^{384}$ FJ was accompanied

\footnotetext{
${ }^{378}$ William Landes \& Richard Posner, Causation in Tort Law: An Economic Approach, 12 J. LEGAL STUD. 109, 13031 (1983), quoted in SHAPO \& PELTZ, supra note 4, at 561.

379 Nytt Juridiskt Arkiv [NJA] [Supreme Court] 2014-06-26 p. 499 T 3592-13 (Swed.), available at http://www.hogstadomstolen.se/Domstolar/hogstadomstolen/Avgoranden/2014/2014-06-26\%20T\%203592-

13\%20Dom.pdf [http://perma.cc/62YB-NERR]; Nytt Juridiskt Arkiv [NJA] [Supreme Court] 2014-06-26 p. 499 T 5507-12 (Swed.), available at http://www.hogstadomstolen.se/Domstolar/hogstadomstolen/Avgoranden/2014/201406-26\%20T\%205507-12\%20Dom\%20skiljaktig.pdf [http://perma.cc/B37B-XPFU] (translated to English by Google Translate. I am grateful to Professor Håkan Andersson for pointing me to these decisions and for providing additional resources of his own authorship on the subject of these cases and Swedish anti-discrimination law in general: Håkan Andersson, Den "Nya" Diskrimineringsersättningen (I)—Nya Explicita Bedömningsgrunder Avseende Upprättelse och Prevention, INFOTORG JURIDIK, Jan. 2015 (reprint on file with author); Den "Nya" Diskrimineringsersättningen (II)—Nya Explicita Bedömningsgrunder Avseende Miniminivå, INFOTORG JURIDIK, Jan. 2015 (reprint on file with author); and Diskrimineringsjuridikens Ersättningsrättsliga Diskurs-en Argumentativ Inventering, 2013 SVENSK JURIST TIDNING 779, available at http://svjt.se/svjt/2013/779.)

${ }^{380}$ Håkan Andersson, Institute, supra note 1, Apr. 10, 2015 (Sweden).

${ }^{381} I d$.

${ }^{382} I d$.

${ }^{383}$ See, e.g., Joanna Kakissis, Sweden's Tolerance Is Tested By Tide Of Syrian Immigrants, NPR MoRnING EDITION, Dec. 5, 2014, http://www.npr.org/sections/parallels/2014/12/05/368640533/swedens-tolerance-is-tested-by-tide-ofsyrian-immigrants [http://perma.cc/E47K-X6NX]; Shaun Ley, Sweden Offers No Easy Immigration Answers, BBC RADIO 4, Aug. 5, 2015, http://www.bbc.com/news/uk-33775796 [http://perma.cc/8SEF-AM5J].

${ }^{384}$ NJA 2014-06-26 p. 499 T 3592-13, III 1-2.
} 
by "FAI" and their infant son in a stroller. ${ }^{385}$ FJ wore a shawl, and FAI, an imam in Eskilstuna, wore a beard. ${ }^{386}$ The bus driver left his seat to confront them and physically removed FJ's knee from its position near the button. ${ }^{387}$ An argument ensued with FAI, in which the driver said “something like that if FJ and FAI do not speak Swedish, they can 'go home to Taliban country.' He also called them idiots. Later, he made an obscene gesture at them." 388 FJ and FAI left the bus and reported feelings of fright, offense, and concern that FAI was recognized in the public encounter. ${ }^{389}$ The discrimination ombudsman sought compensation for FJ and FAI of 100,000 Swedish kronor each (close to US \$12,000 each) for violation of dignity through harassment based on ethnicity and religion. ${ }^{390}$ The lower courts set the award variously at 15,000 kronor each or 20,000 kronor each, differing over the degree of violence the bus driver had exerted on FJ's knee. ${ }^{391}$ Veolia appealed to reduce the award. ${ }^{392}$

In the second case, "DP," a lesbian, sought assistance with fertility at the gynecological clinic of a medical center, "UP," a public agency of Stockholm County in the Liljeholmens district. ${ }^{393}$ Because she is lesbian, the medical center refused to see DP, rather referred her to SÖSAM, a facility of South Hospital, purportedly for that facility's specialization in assisting lesbian couples. ${ }^{394}$ Some days later, DP spoke to a UP gynecologist to ascertain the reason for the referral policy, and subsequently UP did treat DP. ${ }^{395}$ Nevertheless, the discrimination ombudsman

\footnotetext{
${ }^{385}$ Id. II 1.

${ }^{386}$ Id. III $4-5$.

${ }^{387}$ Id. II 3.

${ }^{388}$ Id. (in original, "något i stil med att om FAI och FJ inte talade svenska så kunde de 'åka hem till talibanlandet.' Han kallade dem även för idioter. Senare gjorde han en obscen gest mot dem.”).

${ }^{389}$ Id. IIII 4-5.

${ }^{390}$ NJA 2014-06-26 p. 499 T 3592-13, I[ 9.

${ }^{391}$ Id. II 10.

${ }^{392}$ Id. (Claim in the Supreme Court).

${ }^{393}$ NJA 2014-06-26 p. 499 T 5507-12, II 1.

${ }^{394} \mathrm{Id}$.

${ }^{395}$ Id. II 2.
} 
ordered the Stockholm County Council to pay 100,000 kronor for having disadvantaged DP for reason of her sexual orientation. ${ }^{396}$ Finding no medical justification for the UP referral policy, ${ }^{397}$ the district court awarded DP 15,000 kronor, which the intermediate appellate court ultimately upped to 30,000 kronor. ${ }^{398}$ The discrimination ombudsman appealed for a higher award..$^{399}$

The Swedish Supreme Court took the occasion of these two challenges to clarify the methodology for damages valuation in cases under the anti-discrimination statute. ${ }^{400}$ The valuation has two components, one compensatory, to compensate the plaintiff for harm including pecuniary losses as well as the non-pecuniary loss of moral injury; and the other punitive, to effect deterrence of discrimination in the future. ${ }^{401}$ The compensatory analysis operates according to the usual principles of tort law. ${ }^{402}$ Assessment of moral damages requires analysis of the egregiousness of the offense and the severity of the injury, checked by an objective perspective. ${ }^{403}$ The court must judge "the seriousness of the discrimination by all the negative feelings of humiliation, contempt, deprivation or similar violation - in view of its cause, nature, scope and effects and taking into account the circumstances," including the defendant's intent. ${ }^{404}$

The punitive portion of the award does not depend on tort principles, because Swedish law does not ordinarily permit punitive damages. ${ }^{405}$ The focus is not on compensation, but

\footnotetext{
${ }^{396}$ Id. II 3.

397 Id. II 10.

${ }^{398}$ NJA 2014-06-26 p. 499 T 5507-12, II 4.

${ }^{399}$ Id. (Claim in the Supreme Court).

400 See NJA 2014-06-26 p. 499 T 3592-13, II 26.

${ }^{401}$ NJA 2014-06-26 p. 499 T 5507-12, đI 12.

${ }^{402} \mathrm{Id}$. at para. 13.

${ }^{403}$ NJA, I (T 3592-13) at para. 27; NJA, II (T 5507-12) at para. 13.

${ }^{404}$ NJA, I (T 3592-13) at para. 30 (in original, "allvaret av diskrimineringen efter främst de negativa känslor av förnedring, ringaktande, utsatthet eller liknande som kränkningen — i betraktande av dess orsak, art, omfattning och verkningar och med beaktande av omständigheterna runt denna—typiskt sett är ägnad att framkalla").

$405 I d$. at para. 35 .
} 
prevention. ${ }^{406}$ Presumptively, the punitive award starts as equal to the compensatory award. ${ }^{407}$ The court must then adjust the punitive award upward or downward as circumstances warrant. Factors that press for upward adjustment may include any tangible advantage the defendant obtained because of the discrimination, or a pattern of discriminatory behavior by the defendant. ${ }^{408}$ Culpability, from omission or carelessness to intent, and the seriousness of the offense may dictate upward or downward adjustment. ${ }^{409}$ Downward adjustment may also be warranted by the defendant's mitigation, ${ }^{410}$ such as sincere apology. ${ }^{411}$

In the bus case, the Swedish Supreme Court reduced the award in sum, setting the compensatory award at 15,000 kronor to each defendant and the punitive award at 10,000 kronor to each defendant. ${ }^{412} \mathrm{FJ}$ and FAI suffered emotional and moral harm, but not tangible loss. ${ }^{413}$ The Supreme Court discounted the physical contact with FJ's knee because it could not be tied causally to the bus driver's otherwise discriminatory intent. ${ }^{414}$ The driver's misconduct was serious, aggravated by public circumstances and his failure to mitigate in any way. ${ }^{415}$ Considering preventive factors, though, the Court considered that Veolia reprimanded its driver and sent him for customer service training, and a company representative promptly telephoned FAI and apologized. $^{416}$

\footnotetext{
${ }^{406} I d$.

${ }^{407}$ Id. at para. 36; NJA, II (T 5507-12) at para. 14.

${ }^{408}$ NJA, I (T 3592-13) at para. 37.

${ }^{409} \mathrm{Id}$. at para. $37-38$.

${ }^{410} \mathrm{Id}$. at para. 38 .

411 NJA, II (T 5507-12) at para. 51-52.

${ }^{412} \mathrm{Id}$. at para. 21.

${ }^{413}$ NJA, I (T 3592-13) at para. 42, 47.

${ }^{414} \mathrm{Id}$. at para. 43.

${ }^{415} I d$. at para. 45-46.

${ }^{416} I d$. at para. 50.
} 
In the medical center case, the Supreme Court concluded that an award of only 10,000 kronor was warranted, comprising of 5,000 kronor for compensation and 5,000 kronor for prevention. ${ }^{417}$ The Court let the 30,000 kronor award stand, because the County Council had not appealed. ${ }^{418}$ In this case, the Court struggled to find the minimum appropriate compensatory award, because DP's harm was regarded as minimal. ${ }^{419}$ She had been discriminated against, and the medical center was without justification. ${ }^{420}$ But UP was benevolent in its intentions, meaning to send DP to SÖSAM for better care, and UP later treated DP. ${ }^{421}$ The court considered that statutory compensation for minor violations of the national data protection law sits at 3,000 kronor, and European human rights law finds suspect an award that sums less than 10,000 kronor. ${ }^{422}$ Accordingly, the court set compensation at 5,000 kronor, which, when doubled by an unadjusted punitive award, hit the 10,000 mark. ${ }^{423}$

Though the damages calculations make for a noteworthy precedent, the delegate from Sweden commented on the cases as evidence of an expansive construction of Swedish antidiscrimination law. ${ }^{424}$ Swedish law unremarkably recognizes discrimination based on race, gender, religion, disability, age, and sexual identity. ${ }^{425}$ But the potential for a minimum 10,000 kronor (almost US \$1,200) award in tort arising from an unfortunate but singular incident, even absent malicious intent, threatens to chill everyday social interaction. The delegate suggested that the Court's approach is too permissive of claimants' assertions of injury based on their subjective

\footnotetext{
${ }^{417}$ NJA, II (T 5507-12) at para. 28.

${ }^{418} \mathrm{Id}$. at para. 29.

${ }^{419} \mathrm{Id}$. at para. 17.

${ }^{420} \mathrm{Id}$. at para. 15-16.

${ }^{421} \mathrm{Id}$. at para. 15.

${ }^{422} I d$. at para. 17.

${ }^{423} I d$.

${ }^{424}$ Andersson, Institute, supra note 1.

${ }^{425} \mathrm{Id}$.
} 
perceptions, despite the Court's purported insistence on objective perspective. ${ }^{426}$ While no one condones the conduct of the bus driver, the case used the mechanism of tort law to redress what might have been better classified in Swedish law as an incident of hate speech. ${ }^{427}$ And the Court in the medical center case hit the public treasury with a liability based only on well meaning, if misguided, medical judgment. ${ }^{428}$

The slippery-slope worry accords well with conservative and libertarian anxiety in America over the scope of anti-discrimination law. ${ }^{429}$ Categorical protection in federal law against discrimination has grown from "race or color" in Reconstruction ${ }^{430}$ to embrace religion, ${ }^{431}$ national origin, ${ }^{432}$ gender, ${ }^{433}$ age, ${ }^{434}$ disability ${ }^{435}$ and, most recently in the heralded Supreme Court decision Obergefell v. Hodges, sexual orientation. ${ }^{436}$ Regulation of hate speech in the U.S. has fallen flat against judicial protection for free expression, ${ }^{437}$ marking a distinction from European and other jurisdictions. ${ }^{438}$ At the same time, the U.S. Constitution permits criminal punishment to turn on hateful motives, which may be evidenced by hateful speech, ${ }^{439}$ and probably permits punishment for harassment, which might differ from hate speech only in repetition or degree. ${ }^{440}$

\footnotetext{
${ }^{426} I d$.

${ }^{427} \mathrm{Id}$.

${ }^{428} I d$.

429 See, e.g., DAVID E. BernsteIn, You CAN'T SAY That!: The Growing Threat to CiviL LiBERTIES From ANTIDISCRIMINATION LAW 11-13 (Cato Inst. ed., 2003).

${ }^{430}$ Civil Rights Act of 1866, 42 U.S.C. $\$ 1981$.

${ }^{431}$ Civil Rights Act of 1964, 42 U.S.C. $§ 2000 a$.

${ }^{432} \mathrm{Id}$.

${ }^{433}$ Id. $\$ 701$.

${ }^{434}$ Age Discrimination in Emp't Act of 1967, 29 U.S.C. $\$ 623$.

435 Americans with Disabilities Act of 1990, 42 U.S.C. $§ 12101$.

${ }^{436}$ See Obergefell v. Hodges, 576 U.S.___, (2015).

${ }^{437}$ R.A.V. v. City of St. Paul, Minn., 505 U.S. 377, 402 (1992) (White, J., concurring).

438 SAMUel Walker, Hate SPEech: THE History OF AN AMERICAN CONTROVERSy 1-2 (Univ. of Neb. ed., 1994).

${ }^{439}$ Wis. v. Mitchell, 508 U.S. 476, 487 (1993); see also 18 U.S.C. $§ 249$ (2009).

${ }^{440}$ See Avis Rent A Car Sys. Inc. v. Aguilar, 529 U.S. 1138, 1141 (2000) (Thomas, J., dissenting from cert. denial in case in which state court allowed injunction against employer's use of racial or ethnic epithets to or about Latino employees).
} 
As to damages, U.S. anti-discrimination law also provides for both compensatory and punitive awards, though the specifics vary with statutes. ${ }^{441}$ To generalize, compensatory damages follow tort norms, like in Sweden, though the U.S. norms of course derive from common law rather than judicial construction of civil law. ${ }^{442}$ Constitutional violation cannot support presumed damages, nor any kind of per se compensatory damages. ${ }^{443}$ However, compensatory damages may derive from actual but intangible harms, such as emotional distress, reputational loss, and personal humiliation. ${ }^{444}$ The U.S. Supreme Court rejected damages based on mere constitutional infringement as too likely to result in arbitrary awards, ${ }^{445}$ though appeals courts have allowed for only nominal damages when no compensatory damages can be proved. ${ }^{446}$ Civil rights statutes also authorize punitive damages and sometimes, contrary to the usual "American rule," attorney-fee shifting. ${ }^{447}$ Because punitive damages are known to American common law, the common law provides a ready test, allowing punitive damages for common law malice, i.e., evil motive, or, in the alternative, for recklessness. ${ }^{448}$

The outcomes in the bus and medical center cases would be regarded as overreaching by U.S. legal standards, for much the reason that the delegate from Sweden suggested they are worrisome. The quarrel is not with the categorical expansion of anti-discrimination protection, which is a matter principally for policymakers and not at issue in either case. But the potential overlap of anti-discrimination law with the regulation of hate speech in the bus driver case would

\footnotetext{
441 See generally Mary Ann Sedey, Compensatory and Punitive Damages in Federal Civil Rights Actions (2005) (unpublished paper submitted to annual Labor and Employment Law Conference of American Bar Association), http://apps.americanbar.org/labor/lel-aba-annual/papers/2005/033.pdf. [http://perma.cc/PW6F-5QNR].

44242 U.S.C. § 1988(a) (2000); Memphis Cmty. Sch. Dist. v. Stachura, 477 U.S. 299, 306 (1986) (construing 42 U.S.C. § 1983).

${ }^{443}$ Stachura, 477 U.S. at 311-12.

${ }^{444} I d$. at 307.

${ }^{445}$ Id. at 310 .

${ }^{446}$ Hazle v. Crofoot, 727 F.3d 983, 993 (9th Cir. 2013).

${ }^{447}$ E.g., 42 U.S.C. $§ 1988($ b).

${ }^{448}$ Smith v. Wade, 461 U.S. 30, 48 (1983) (citing RESTATEMENT (SECOND) OF TORTS § 908(2) (1977)).
} 
be highly problematic in the U.S. because of the constitutional protection for the speech. Without a causal link to the bus driver's touching of FJ's knee, or a purposeful ejection of FJ and FAI from the bus, there is no other unlawful, predicate action that can be tested for discriminatory motive. Absent also are the pattern or severity that would characterize harassment. So in U.S. law, such a discrete event, however repugnant, would remain a matter of employee discipline and customer care.

A similar result would pertain in the medical center case. U.S. federal statutes do not prohibit sexual-orientation discrimination; moreover, municipal entities are immune from liability under the flagship federal civil rights law, 42 U.S.C. $§ 1983$, because of federalism constraints. ${ }^{449}$ The recent Obergefell doctrine in U.S. constitutional law reaches public actors under the state action doctrine, but the contours of the constitutional rule, and whether it operates beyond marriage at all, will be years in the mapping. More saliently, on the damages question, the 10,000-krona award in the Swedish case seemed to be a compensation for rights violation per se. Damages in U,S. civil rights law, derived as they are from common law tort, are measured subjectively; DP would have to prove actual loss, even if intangible, to win damages. And punitive damages would not be available upon a defendant's benevolent motive. Even if DP could get to a nominal award, it likely would be symbolic and negligible in sum.

${ }^{449}$ Monell v. N.Y.C. Dep’t of Soc. Serv., 436 U.S. 658, 690-92 (1978). 


\section{E. Class Actions: France And the CASE OF The Consumer Collective}

France as well as other countries adopted new laws authorizing or expanding consumer class action litigation, ${ }^{450}$ and the French delegate ${ }^{451}$ focused on the change. ${ }^{452}$ Europe has been slow to develop collective action, and conventional wisdom states that perceived excesses against enterprise in the U.S. have been cautionary. France exemplifies such caution, so the enactment of the law_in development since 2010 and following "decades of debate" ${ }^{453}$ — marks a milestone, even though the law is comparatively limited in scope. ${ }^{454}$ French legislators were motivated by public demand after a series of ugly product defect incidents. ${ }^{455}$

\footnotetext{
${ }^{450}$ Professor Durant from Belgium, supra note 56, split her time discussing the case I selected for discussion in part II.A, supra, and Belgian class action legislation. Other delegates in their comments, supra note 1, noted that their countries too had innovated in class action legislation, though they had not chosen that topic for discussion. See also Roman Madej, EU Class Actions Gather Pace-Bill Before Belgian Parliament, Bryan CAVE (Feb. 5, 2014), http://www.eu-competitionlaw.com/eu-class-actions-gather-pace-bill-before-belgium-parliament/\#

[http://perma.cc/5YND-QACR]. See generally Verica Trstenjak \& Petra Weingerl, Collective Actions in the European Union-American or European Model?, 5 BEIJING L. REV. 155 (2014), http://dx.doi.org/10.4236/blr.2014.53015 [http://perma.cc/VL3R-HN6K], (reviewing legal developments at European federal level). I focus here on France rather than Belgium because the French law derives some unusual features from deliberate divergence with U.S. law. For a review of European class action legislation, see ClASS ACTIONS IN EUROPE AND THE UNITED STATES 5-57 (Georg Lett \& Sofie Vang Kryger eds., Sept. 2014), http://www.libralex.com/publications/class-actions-in-europeand-the-us [http://perma.cc/N2ZQ-J8YT] (last visited July 10, 2015).

${ }^{451}$ Michel Séjean, Institute, supra note 1, (France).

${ }^{452}$ Loi n $^{\circ}$ 2014-344 du 17 mars 2014 relative à la consummation [Law no. 2014-344 of Mar. 17, 2014, regarding consumers], Journal Officiel de la République Française [J.O.] [Official Gazette of France], Mar. 18, 2014, p. 5400, art. 1, http://www.legifrance.gouv.fr/affichTexte.do?cidTexte=JORFTEXT000028738036\&categorieLien=id [http://perma.cc/P9NL-JMJF]. The law also enhanced the substantive scope of consumer rights. See generally Thomas Oster, Adoption of the "Loi Hamon" Consumer Bill: Overview of the Main Provisions, LeXOLOGY (Feb. 26, 2014), http://www.lexology.com/library/detail.aspx?g=4256f052-aae8-421d-8e22-4f7b966068c0 [http://perma.cc/YJ5LQ2BT]. However, note that many provisions of the code as enacted in 2014 did not survive constitutional scrutiny. See Law no. 2014-344 (passim, "[Dispositions déclarées non conformes à la Constitution par la décision du Conseil constitutionnel no 2014-690 DC du 13 mars 2014.]" (original emphasis)).

${ }^{453}$ Louise-Astrid Aberg, Raimbaut Lacoeuilhe, \& Lionel Lesur, France Finally Embraces Class Actions, MCDERMOTT WILL \& EMERY (Mar. 2014), http://www.mwe.com/France-Finally-Embraces-Class-Actions-02-272014/ [http://perma.cc/223Z-QHYK] [hereinafter Aberg].

${ }^{454}$ The development of the law from 2010 conception to 2014 enactment is summarized in Marc E. Shelley \& Emily R. Fedeles, New French Class Action Law Could Span the Gamut, LAw360 (May 5, 2014), https://advance.lexis.com/api/permalink/f57db13f-78d9-488e-ab19-5fe63c336916/?context=1000516 (Lexis Advance).

${ }^{455} \mathrm{Id}$. (reporting incidents involving breast implants, horsemeat, and "a diabetes drug, which had also been prescribed as an appetite suppressant, ... allegedly responsible for the deaths of as many as 2,000 people and cardiovascular complications in countless others"). The first lawsuit under the new law, filed immediately upon its effective date in October 2014, involved real estate rental fees that renters alleged were illegal. Ozan Akyurek \& Clémence de Perthuis,
} 
A noteworthy feature of the French law at the outset is that it authorizes only consumer organizations registered with the national government-of which there were only fifteen or sixteen when the law was adopted ${ }^{456}$ — to act as plaintiffs on behalf of consumers. ${ }^{457}$ Thus actions cannot be initiated by other organizations, nor by attorneys as representatives of consumers, nor on behalf of consumers other than natural persons. ${ }^{458}$ The disallowance of attorney-led classes represents a deliberate rejection of the U.S. model for collective action. ${ }^{459}$ French legislators perceived the U.S. model as prone to excess because attorneys are motivated by their own financial remuneration too often to the exclusion of the consumers' best interests. ${ }^{460}$

Consistency of claims is ensured by requiring that represented consumers suffered similar loss from the same failure of obligation on the part of the defendant. ${ }^{461}$ A certification process occurs upon a plaintiff-favorable outcome on exemplary cases presented to the civil court. ${ }^{462}$ Class participation ordinarily works on a consumer opt-in basis. ${ }^{463}$ However, the law provides an alternative procedure for cases in which the consumer class is limited in number and fully identifiable, and consumers each suffered the same loss. ${ }^{464}$ In such cases, after certification, the court may award damages directly to the identified consumers without the delay of an opt-in procedure. ${ }^{465}$ The French law allows recovery only for pecuniary losses in consumer and

First-Ever Class Action Filed in France, JONES DAY (Oct. 2014), http://www.jonesday.com/first-ever-class-actionfiled-in-france-10-21-2014/ [http://perma.cc/T3QG-S6AE].

${ }^{456}$ Shelley \& Fedeles, supra note 454; Aberg, supra note 453.

${ }^{457}$ Law no. 2014-344 art. 1 (amending C. CONSUMMATION bk. IV, tit. II, new ch. III, § 1).

${ }^{458}$ Séjean, Institute, supra note 1; Aberg, supra note 453.

${ }^{459}$ Séjean, Institute, supra note 1.

${ }^{460} I d$.

${ }^{461}$ Law no. 2014-344 art. 1 (amending C. CONSUMMATION bk. IV, tit. II, new ch. III, § 1).

${ }^{462}$ Id. (amending C. Consummation bk. IV, tit. II, new ch. III, § 2); Shelley \& Fedeles, supra note 454.

${ }^{463}$ Law no. 2014-344 art. 1 (amending C. ConsumMATION bk. IV, tit. II, new ch. III, § 2); see also Shelley \& Fedeles, supra note 454; Séjean, Institute, supra note 1.

${ }^{464}$ Law no. 2014-344 art. 1 (amending C. Consummation bk. IV, tit. II, new ch. III, § 3).

${ }^{465}$ Id. (amending C. Consummation bk. IV, tit. II, new ch. III, § 3); see also Shelley \& Fedeles, supra note 454. Compare Séjean, Institute, supra note 1 ("not far from an opt out system?"), with Oster, supra note 452 ("('opt-out' system)"), and with Aberg, supra note 453 ("not an opt-out procedure but a specific and unique opt-in procedure"). 
competition law ${ }^{466}$ - thus, significantly and curiously, not for physical injury, nor for environmental harms. ${ }^{467}$

The French law has been criticized from the western side of the Atlantic, in part, for being too cautiously reactionary to U.S. class action practice. ${ }^{468}$ Based on exemplary cases, the timing of the responsibility determination because the process precedes class certification. ${ }^{469}$ Unaware of the full class membership, the defendant might be deprived of the opportunity to raise defenses that would be effective against only some individual consumers. ${ }^{470}$ Inversely, absent class members might suffer because of a pre-certification decision in the defendant's favor. ${ }^{471}$ Shelley and Fedeles reported that the ordering of events was a deliberate legislative choice, as socialistparty proponents of the legislation feared that earlier class certification would bog things down. ${ }^{472}$ The attorneys also criticized the French law for its lack of a consolidation process, potentially forcing defendants to litigate similar cases in different civil courts, and possibly affording plaintiff more than one bite at the apple. ${ }^{473}$

Of course U.S. class action practice has its supporters and critics, both at home and abroad, and is itself a work in progress. Andrew Trask, an American lawyer based in London, recently reported on comparative discussion of U.S. and European approaches to collective redress. ${ }^{474}$ Trask's observations show European systems, like France, struggling with issues such as how to

\footnotetext{
${ }^{466}$ Law no. 2014-344 (amending C. ConsumMation bk. IV, tit. II, new ch. III, § 1).

${ }^{467}$ Shelley \& Fedeles, supra note 454; Séjean, Institute, supra note 1.

${ }^{468}$ Aberg, supra note 453.

${ }^{469}$ Shelley \& Fedeles, supra note 454.

${ }^{470} I d$.

${ }^{471} I d$.

${ }^{472} I d$.

${ }^{473} I d$.

${ }^{474}$ Andrew J. Trask, Perfecting The (European) Class Action, Class ACTION COUNTERMEASURES, (July 7, 2015), http://www.classactioncountermeasures.com/2015/07/articles/uncategorized/perfecting-the-european-classaction/[http://perma.cc/L5M2-AWWS].
} 
ensure the clients' best interests over attorneys'; how to attain claim consistency; whether to allow opt-out litigation; and how to handle multi-jurisdictional cases to avoid parallel claims and manage cross-border disputes. ${ }^{475}$ In this light, Trask lauded "the particular genius" of the multi-factor class certification process in U.S. Federal Rule of Civil Procedure $23,{ }^{476}$ in particular the class criteria of "numerosity, commonality, typicality, and adequate representation." ${ }^{477}$ At the same time, Trask concluded that there is room to learn from study of Europe's experiments. He opined that "a less expansive Rule 23" would not mean "the death of collective redress," and strict construction of Rule 23 "will not kill the class action; nor will it create a corporate-ruled dystopia."

In just that vein, U.S. legislators who share the European concern that class action latitude hampers enterprise introduced a bill in April 2015; the "Fairness in Class Action Litigation Act of 2015" would tighten the certification process by requiring the petitioner for certification "affirmatively [to] demonstrate[] through admissible evidentiary proof that each proposed class member suffered an injury of the same type and extent as the . . class representative." ${ }^{479}$ This proposal complements an apparent inclination the U.S. Supreme Court has expressed in its rejection of class actions under Rule 23 in 2011 with Wal-Mart Stores, Inc. v. Dukes ${ }^{480}$ and in 2013 with Comcast Corp. v. Behrend. ${ }^{481}$ The Court shook up the class action landscape when it found consistency lacking in Wal-Mart. It rejected plaintiffs' certification theory of employment discrimination through local supervisors' discretion without proffer of common discriminatory

\footnotetext{
${ }^{475} \mathrm{Id}$.

${ }^{476} I d$.

477 Wal-Mart Stores, Inc. v. Dukes, 131 S. Ct. 2541, 2550 (2011) (characterizing FED R. CIV. P. 23(a)).

478 Trask, supra note 474.

${ }^{479}$ H.R. 1927, 114th Cong., 1st Sess. (introduced Apr. 22, 2015).

${ }^{480}$ Wal-Mart, 131 S. Ct. 2541.

${ }^{481}$ Comcast Corp. v. Behrend, 133 S. Ct. 1426, 1429 (2013); see also Genesis Healthcare Corp. v. Symczyk, 133 S. Ct. 1523, 1532 (2013) (rejecting collective action under Fair Labor Standards Act, 29 U.S.C. § 216(b), as moot, distinguishing FED R. CIV. P. 23, when defendant offered full satisfaction to named plaintiff).
} 
exercises, despite plaintiffs' statistical and anecdotal evidence. ${ }^{482}$ The Court further tightened the gantlet in Comcast Corp. when it rejected a class of more than two million cable TV subscribers, holding that the plaintiffs' statistical proof of defendant's anticompetitive pricing did not sufficiently demonstrate consistent loss across the class. ${ }^{483}$

Now the Court has granted certiorari in another class action challenge to be heard in the 2015-16 term. ${ }^{484}$ This latest case again puts consistency front and center. The Eighth Circuit, relying on plaintiffs' statistical model, affirmed class certification in an employment undercompensation suit, in which defendant and industry giant Tyson Foods asserted prohibitive variation in employees' work gear, work routines, and departmental duties and management. ${ }^{485}$ Perhaps lending credence to European suspicions, Circuit Judge Clarence Arlen Beam, who dissented, ${ }^{486}$ characterized the case as "yet another manifestation of a professionally assembled class action lurching out of control." 487

\footnotetext{
${ }^{482}$ Wal-Mart, 131 S. Ct. at 2550-57 (construing FED. R. CIV. P. 23(a)). The Court also found the erroneously certified under Rule 23, because the plaintiffs sought monetary relief in back pay, not incidental to injunctive relief. Id. at 255761 (construing FED R. CIV. P. 23(b)(2), one of three alternative bases for class action described by subpart (b), to permit class seeking only injunctive and incidental monetary remedy).

${ }^{483}$ Comcast, 133 S. Ct. at 1437-41 (construing FED. R. CIV. P. 23(b)(3), one of three alternative bases for class action described by subpart (b), which requires "that the questions of law or fact common to class members predominate over any questions affecting only individual members, and that a class action is superior to other available methods for fairly and efficiently adjudicating the controversy").

${ }^{484}$ Bouaphakeo v. Tyson Foods, Inc., 765 F.3d 791, 797, reh'g denied, 593 F. Appx. 578 (8th Cir. 2014), cert. granted, No. 14-1146, 83 U.S.L.W. 3765, 3883, 3888, 2015 WL 1278593 (mem.) (U.S. June 8, 2015); see also Brent Kendall, Supreme Court to Hear Case Offering Opportunity to Limit Class-Action Suits, WALL. ST. J. (June 8, 2015), http://www.wsj.com/articles/supreme-court-to-hear-case-offering-opportunity-to-limit-class-action-suits-

1433787388 [http://perma.cc/EJV9-RJMB]. The case features both a Rule 23 class certification and, as in Genesis Healthcare, 133 S. Ct. 1523, see supra note 481, a collective action under the Fair Labor Standards Act, 29 U.S.C. $\S 216(\mathrm{~b})$.

${ }^{485}$ Bouaphakeo, 765 F.3d at 797, 800.

${ }^{486} \mathrm{Id}$. at 800-05 (Beam, Cir. J., dissenting).

${ }^{487}$ Bouaphakeo, 593 F. Appx. at 578 (Beam, Cir. J., dissenting).
} 


\section{ANALYSIS}

Delegates to the 2015 conference of the European Tort Law Institute presented cases and statutes of interest from their respective countries, and a number of themes recurred in those presentations: (a) damages valuation and compensation for life and death; (b) multiple liabilities; (c) the interplay of tort and insurance; (d) official liability and civil rights; and (e) consumer class actions. Though most of the European countries are civil code jurisdictions, these themes raise issues common to code and common law jurisdictions, and common to U.S. and European tort law.

Cases from seven countries showed courts struggling with the problem of quantifying loss along a broad spectrum, from a ritzy car to the hedonic value of life itself. ${ }^{488}$ An Estonian court scrutinized a fisherman's need to replace his BMW. ${ }^{489}$ A Finnish court considered the consequences of a lost year at university. ${ }^{490}$ A Maltese court wrestled with the value of homemaking, ${ }^{491}$ and a Slovak court with the value of social life. ${ }^{492}$ Belgian and Portuguese jurists contemplated the impact on family of severe disability. ${ }^{493}$ And an Italian court contemplated the hedonic value of life in contrast with the emptiness of death, recognizing "thanatological" damages in contrast with biological loss. ${ }^{494}$

All of these outcomes under civil codes accorded roughly with their disposition in U.S. common law tort, except the new direction marked by Italy, which is on subsequent appeal there. The motivations underlying the constructions of civil code and the development of U.S. common law focus on the same essential rationale, which is to make the plaintiff whole with a monetary

\footnotetext{
488 See supra part II.A.

${ }^{489}$ See supra part II.A.1.

${ }^{490}$ See supra part II.A.2.

${ }^{491}$ See supra part II.A.3.

${ }^{492}$ See supra part II.A.4.

${ }^{493}$ See supra parts II.A.5 \& 7.

${ }^{494}$ See supra part II.A.6.
} 
proxy for consequential losses, subject to the rigors of proof. The systems were consistent toward full compensation, as in the consequences of higher education denied. Courts in both systems also evinced similar suspicion of claims less concrete, farther detached from physicality, as in the Slovakian insistence on proof of social injury in comparison with the powerful U.S. aversion to double recovery. The systems also were consistent where they arguably fell short of full recovery, as in fully and fairly quantifying the value of homemaking, and in measuring the lifetime costs to care for a child born with severe and permanent disability.

A difference manifested in some European courts' reliance on European federal or other international law, especially the fundamental value placed on the integrity of the person. Insisting that homemaking must be positively valued, economically, the court in Malta pointed to European human rights as incorporated into European law with the Treaty of Lisbon. U.S. courts have found their way to that outcome without explicit reference to constitutional notions of personal liberty. The Belgian court pointed to the rights of children, even the unborn, both in European human rights and in global international instruments, to limit recovery for "wrongful life," or "wrongful birth." U.S. courts have recognized the same logic in public policy to reach a comparable outcome, but refrain from implicating constitutional rights as a basis. The Portuguese court pointed to panEuropean tort principles, along with precedents from three other western European countries, to construe the Portuguese civil code to favor spousal recovery for suffering when an injured person survives. States in the U.S. vary in their approach to the problem.

Cases from five countries showed courts hashing out problems in multiple liabilities, including plaintiff's own fault, imputed fault, vicarious liability, and an empty chair. ${ }^{495}$ A German court refused to find a plaintiff's contributory negligence in failure to wear a bicycle helmet when

\footnotetext{
${ }^{495}$ See supra part II.B.
} 
statute did not require one. A Greek court held a hospital liable for misdiagnosis by its nonemployee doctors. An Irish court allowed a dated claim of child sex abuse under an extended statute of limitation, but charged the plaintiff with the fault of a secondarily culpable empty chair. A Norwegian court reduced the tax on a family for a decedent loved one's contributory fault for drunk driving. And a Slovenian court allowed a woman to recover when bitten by her own dog on the rationale that her parents were the dog's legal custodians.

These outcomes, all under civil codes save Ireland's, find analogs in U.S. common law tort. The animating principle behind the European decisions is equity with a dash of judicial restraint. The Irish decision was a straightforward application of equity, equally at home in the U.S., in charging the plaintiff rather than the defendant for late filing. ${ }^{496}$ The German court was vexed by the prospect of assuming a legislative role, though its helmet decision was informed equitably with reticence to award the defendant a windfall. ${ }^{497}$ Though divided on helmet laws, U.S. courts likewise cite windfalls and fairness while quietly nursing a jealous fealty to corrective justice. The Greek decision considered the fair perception of responsible parties from the plaintiff's point of view, just as the U.S. common law boasts the doctrine of ostensible agency. ${ }^{498}$ The Slovenian decision likewise turned on the parties' mutually understood, de facto roles, if to the displeasure of the defendants' insurer. ${ }^{499}$ That outcome would pertain in the U.S. Norway similarly conferred on plaintiffs an equitable advantage after reasoning that the defendant's insurer would be the one to pay the tab. ${ }^{500}$ That outcome is the most peculiar to U.S. common law norms, but it

\footnotetext{
496 See supra part II.B.3.

497 See supra part II.B.1.

498 See supra part II.B.2.

${ }^{499}$ See supra part II.B.5.

${ }^{500}$ See supra part II.B.4.
} 
also was peculiar to Norwegian norms. Both systems feature the odd, equity-driven exception in which a court has been willing to parse the fault that ordinarily would be imputed to survivors.

A Latvian case, a European federal case, and a Spanish statute all implicated the interplay of tort and insurance law. ${ }^{501}$ In Latvia, the interposition of a commercial driver's criminal fault severed the chain of responsibility between the individual driver and the insured vehicle owner. ${ }^{502}$ A statute in Spain shifted the responsibility for some animal-vehicle collisions to compulsorily insured drivers, even when hunters play a causal role in the accident. ${ }^{503}$ And the Court of Justice construed the European law of compulsory vehicle insurance with a definition of "use" that afforded a plaintiff victim of a farm tractor accident a chance to recover from the tractor's insurer..$^{504}$

These outcomes are not incompatible with U.S. law, but at the same time cannot be generalized as accordant. Though common law tort in the U.S. heavily implicates insurance law, the latter is a creature substantially of contract law and insurance regulation by statute and administrative law in the states. The result of all that fine-tuning by the political branches is a range of insurance systems that reflect local policy predilections. In this system, state courts have divided on the question presented in Latvia, in part a function of judicial willingness to be "activist," 505 i.e., to void contract terms as against public policy, as might favor a claimant, rather than sticking to the contract text to preclude insurer liability. Understanding that insurers draft adhesion contracts, an American rule of construction puts a thumb in the scale in favor of the insured in case of ambiguity, thereby driving more plaintiff-favorable decisions that one might expect in a legal

\footnotetext{
${ }^{501}$ See supra part II.C.

${ }^{502}$ See supra part II.C.1.

${ }_{503}^{503}$ See supra part II.C.2.

${ }^{504}$ See supra part II.C.3.

505 I use a loaded term. See, e.g., S.M., Those "Activist" Judges, ECONOMIST (July 8, 2015), http://www.economist.com/blogs/democracyinamerica/2015/07/judicial-politics-0 [http://perma.cc/3Q2K-8LJN].
} 
system dominated by libertarian, freedom-to-contract principles. That thumb motivates the same occasional deviation from the contract that the strident dissent would have favored in the Latvian case.

The Spanish statute and the CJEU result derogate from U.S. norms. In the case of Spain, the reporting delegate recognized the code amendment as an unusual change, possibly evidencing the political influence of a special interest group. Certainly U.S. law sees similar statutory variations, such as skier responsibility statutes, to protect local economic interests. Risk of loss shifts to first party insureds, and premiums go up, whether for drivers in the Andalusian Sierra Nevadas or for recreational skiers in the Colorado Rockies. The CJEU result in favor of plaintiff Vnuk was surprising only insofar as a U.S. insurer ordinarily would take care to disclaim (or embrace, and charge for) such liability. But the court's reasoning, simply construing a term in European law that had been imported into Slovenian law and contract, squared well with the U.S. rule of construction that favors the insured in case of ambiguity. Thus in both the Spanish and EU cases, the mode of law-making and construction was the same, even if the outcomes were specific to culture and context.

Cases from seven countries, five of them code jurisdictions, showed European courts tackling problems in official liability and the application of public norms, namely antidiscrimination, to private parties. ${ }^{506}$ The Croatian court remarkably used a case of a jilted appointee to public office to create potential state liability under a legislative duty of care. ${ }^{507}$ The Czech court managed a manipulation of procedure to afford a plaintiff in wrongful search and seizure access to civil recovery. ${ }^{508}$ The Polish Supreme Court saw a plaintiff-soldier to recovery for severe illness

\footnotetext{
506 See supra part II.D.

507 See supra part II.D.1.

${ }^{508}$ See supra part II.D.2.
} 
and careless treatment, despite the military milieu of his infection and care. ${ }^{509}$ The Romanian court held the state responsible to a local airport for interference with its operations, resisting the government defendant's bid to treat its highway construction as a state taking for the public good. ${ }^{510}$ The Hungarian court protected journalists from civil liability to police officers for violating their privacy by publishing photographs of them. ${ }^{511}$ The English court, in common law, refused to let the defense of illegality block claims against a defendant who abused a foreign au pair, even though the alien au pair had initially been complicit in the plan to overstay her visitor's visa. ${ }^{512}$ And the Swedish court pushed out the boundary of civil liability in two anti-discrimination cases, even while one involved a case more aptly described as hate speech, and the other involved a case of benevolent, if misguided, intentions. ${ }^{513}$

Unsurprisingly, human rights norms animated many of the decisions in this area. The Croatian court cited European human rights in support of the appointee's expectations, vis-à-vis legislative discretion. The Romanian and Polish decisions implicated individual rights implicitly insofar as both allowed recovery against the state and over its claims to sovereign prerogative. The Czech and Hungarian courts cited European human rights, the latter generalizing into the broad notion of personal integrity and balancing against freedoms of expression and information. The English court cited international condemnation of human trafficking to demonstrate the weight of that wrong in comparison with the lesser violation of national immigration law. And the Swedish court decided that discrimination warranted a significant damages award even with minimal emotional, if any actual, injury, and a well intentioned, if misguided, defendant.

\footnotetext{
${ }^{509}$ See supra part II.D.3.

510 See supra part II.D.4.

511 See supra part II.D.5.

512 See supra part II.D.6.

${ }^{513}$ See supra part II.D.7.
} 
The straightforward Romanian decision accords with notions of official liability in the U.S. Waiver of sovereign immunity varies by state, but appropriate cases tend to be channeled into tort rather than takings, if not without exception. Also Czech operationalization of the right of privacy through the civil code has a U.S. analog in the realization of constitutional remedies in the U.S. through the functional mechanism of tort law. The Czech court's procedural machinations are reminiscent of a Bivens ${ }^{514}$ action with its apparent lack of statutory authorization, yet still landing a plaintiff in "constitutional tort."

The Croatian and Polish decisions are at odds with U.S. norms, but their divergences merit study. The Croatian decision at first blush marks a radical doctrine by U.S. standards. Yet the theory advanced in that case enjoys a not-so-secret life in U.S. litigation, in the guise of the public trust doctrine. Substantial hurdles erected by the American constitutional design might mean the doctrine never gains traction in the U.S. law. But the coincidence of efforts to hold legislators accountable, against all odds, is striking.

The Polish decision also seems surprising by U.S. standards, given the Feres doctrine. Yet the difference bears understanding if one considers timing. The Polish judiciary is relatively young as a democratic instrument, dating only to the country's 1989 liberation from the Soviet sphere. In contrast, the Feres doctrine owes its breadth to the early Cold War, when the Supreme Court produced other curious wonders such as the state secrets privilege. ${ }^{515}$ Perhaps Feres too will have its wings clipped in the future. ${ }^{516}$

\footnotetext{
${ }^{514}$ Bivens v. Six Unknown Agents, 456 F.2d 1339 (1972) (authorizing suit in manner similar to that set forth in 42 U.S.C. $§ 1983$, but under Constitution directly, for the violation of individuals' constitutional rights by state officials acting under color of state law).

515 See U.S.. v. Reynolds, 345 U.S. 1 (1953). See generally BARRY SIEgel, ClaIM OF PRIVILEGE: A MYSTERIOUS Plane Crash, a LANDMARK SUPREME Court CASE, AND THE RiSe OF STATE SECRETS (2009) (investigating Reynolds and explaining how false military pretenses supported expansive state secrets privilege during early Cold War).

516 The state secrets privilege as articulated broadly in Reynolds, 345 U.S. 1, was (at least on paper) sharply curtailed by order of the U.S. Attorney General after the U.S. was sobered by post-9/11 excesses. See Attorney General
} 
The Swedish cases also awarded liability to an extent that U.S. law would not countenance. There was no dispute in the cases, even from the defendants, that their conduct or the conduct of their agents was socially unacceptable. Both cases involved acts of animus against persons for reason of their membership in protected classes recognized to some extent in both Swedish and U.S. law. But the damages awards in both cases lend credence to conservative and libertarian observers in the U.S. who worry that tort liability for psychic harms tends to aggrandize its reach. The slippery-slope argument forecasts a creeping chilling effect on everyday social and economic activity that might be otherwise regulated, or might be unregulated because of a competing public policy such as free expression.

Finally, a number of European countries, France exemplarily in this study, are experimenting with expanded class action litigation. ${ }^{517}$ Adopters are cautious, and opponents on edge, for fear of excesses perceived in U.S. class action litigation under Federal Rule of Civil Procedure 23. Accordingly, European actions are as yet largely limited to opt-in mechanisms. And elaborate competing experiments are under way to accomplish class identification, certification, and representation, employing tools such as certified consumer rights advocates, limited-purpose plaintiff corporations, and representative adjudications. Sometimes implicating substantial transaction costs, these mechanisms aim to stave off the perceived thirst of a vampire plaintiffs' bar that would feast on client and defendant alike, compromising public interest and hampering economic development. Meanwhile steady streams of bills and lawsuits in the U.S. squawk their own doubts about Rule 23, and consumer activists shudder with angst at every blow. So on both

Memorandum re Policies and Procedures Governing Invocation of the State Secrets Privilege (Sept. 23, 2009), http://www.justice.gov/sites/default/files/opa/legacy/2009/09/23/state-secret-privileges.pdf [http://perma.cc/B4XLZQW4] (last visited July 15, 2015).

517 See supra part II.E. 
sides of the Atlantic, policymakers and jurists brawl and labor to build a better mousetrap for collective redress.

\section{CONCLUSIONS}

These reports from Europe, compared alongside developments in American tort law, are suggestive of three observations.

First, when controversy centers on the mundane logistics of tort law, such as damages valuation and liability apportionment, there is great commonality between the U.S. and Europe. Similar problems are presented, and courts employ similar tort values-e.g., making plaintiffs whole, deterrence, equity, and fairness - to resolve these problems. European courts in this vein are far more likely than U.S. courts to state the explicit influence of human rights norms, whether derived from national, supra-national, or international instruments, especially when bound to construe civil codes. But U.S. courts often follow a similar course of reasoning, relying more vaguely on the role of equity and public policy in shaping the common law.

Second, when political policymaking comes into play, it manifests its influence over tort law, perhaps by loading the dice for one class of litigant at the expense of another, or by implementing a broader project, such as compulsory insurance, no-fault liability, or collective redress. The different policy priorities of legislators in the states of the U.S. and in the countries of Europe mean that outcomes under these legislative curvatures vary with local agendas. But U.S. and European courts both tend to heed legislative initiative, respecting the division between corrective and distributive justice. U.S. courts might be somewhat less inclined than European courts to let their own policy priorities, such as the protection of fundamental rights, supervene upon libertarian and democratic prerogatives. But the hand of policy is hardly invisible in U.S. case law when ambiguity opens the door to judicial insight. 
Third, when public liability is at issue, the recent European decisions demonstrate a willingness — at least lucid, at most enthusiastic — to embrace plaintiffs' causes as against the state. Sovereign immunity yielded to plaintiff claims in all of the reported cases from code jurisdictions, or inversely, private defendants prevailed against public official-plaintiffs in Hungary. The Croatian court opened the door to a radical theory of legislative duty to an individual claimant, and the Swedish court allowed damage awards in discrimination cases against both public and private defendants upon a singular incident or a minimal proof. At common law, the English court found its way to an exception to an exception to tort liability, facilitating human rights enforcement against a private defendant. All of these cases accord with the U.S. model of constitutional enforcement through the functional apparatus of tort. But Europe seems far more disposed to judicial preeminence in the constitutional field than the U.S. And that disparity is consistent with a number of factors: evolving human rights norms embodied in the European charter and interpreted contemporaneously in human rights case law; the ascending eminence of harmonization in European law; and the rapid social development of Eastern Europe in the last 25 years.

It must be restated that these reports are not necessarily indicative of trends in Europe. But they are highly informative in that they reflect changes that European legal scholars find compelling. Accepting this limitation, this study of comparative tort law aims, at minimum, to arm legal thinkers and law makers with alternative perspectives in the common pursuit of civil justice. 